Prepared in cooperation with the U.S. Fish and Wildlife Service

\title{
Optimization of Salt Marsh Management at the Rachel Carson National Wildlife Refuge, Maine, Through Use of Structured Decision Making
}

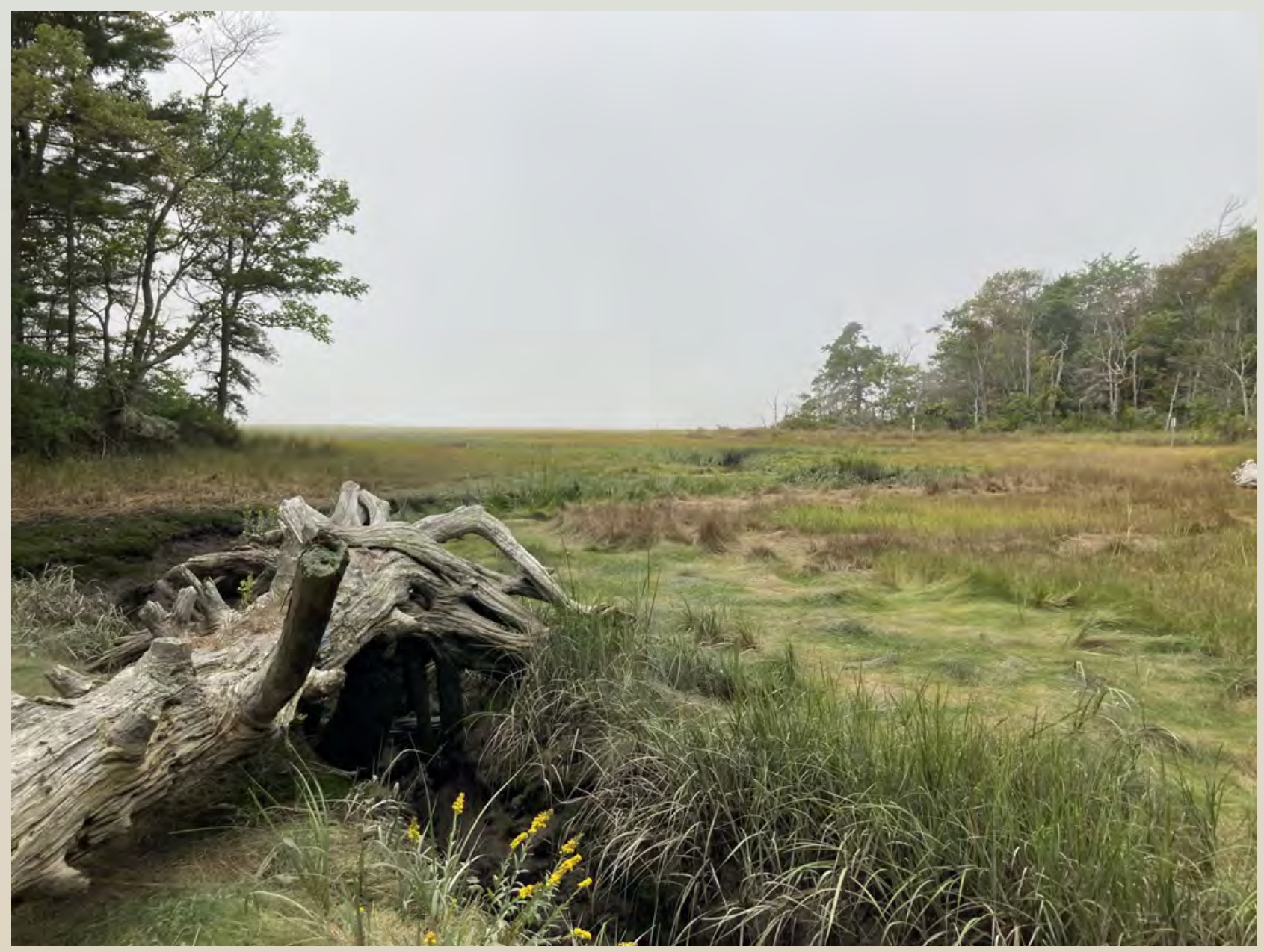

Open-File Report 2021-1080 
Cover. Photograph of Mousam River marsh management unit at the Rachel Carson National Wildlife Refuge, Kennebunk, Maine; photograph by the U.S. Fish and Wildlife Service. 


\section{Optimization of Salt Marsh Management at the Rachel Carson National Wildlife Refuge, Maine, Through Use of Structured Decision Making}

By Hilary A. Neckles, James E. Lyons, Jessica L. Nagel, Susan C. Adamowicz, Toni Mikula, Kathleen M. O’Brien, Bri Benvenuti, and Ryan Kleinert

Prepared in cooperation with the U.S. Fish and Wildlife Service

Open-File Report 2021-1080 


\section{U.S. Geological Survey, Reston, Virginia: 2021}

For more information on the USGS - the Federal source for science about the Earth, its natural and living resources, natural hazards, and the environment—visit https://www.usgs.gov or call 1-888-ASK-USGS.

For an overview of USGS information products, including maps, imagery, and publications, visit https://store.usgs.gov/.

Any use of trade, firm, or product names is for descriptive purposes only and does not imply endorsement by the U.S. Government.

Although this information product, for the most part, is in the public domain, it also may contain copyrighted materials as noted in the text. Permission to reproduce copyrighted items must be secured from the copyright owner.

The findings and conclusions in this report are those of the authors and do not necessarily represent the views of the U.S. Fish and Wildlife Service.

Suggested citation:

Neckles, H.A., Lyons, J.E., Nagel, J.L., Adamowicz, S.C., Mikula, T., O’Brien, K.M., Benvenuti, B., and Kleinert, R., 2021, Optimization of salt marsh management at the Rachel Carson National Wildlife Refuge, Maine, through use of structured decision making: U.S. Geological Survey Open-File Report 2021-1080, 35 p., https://doi.org/10.3133/ ofr20211080.

Associated data for this publication:

U.S. Fish and Wildlife Service [FWS], 2016, Salt marsh integrity and Hurricane Sandy vegetation, bird and nekton data: U.S. Fish and Wildlife Service database, accessed March 16, 2021, at https://ecos.fws.gov/ServCat/Reference/ Profile/121918.

ISSN 2331-1258 (online) 


\section{Acknowledgments}

Ward Feurt of the U.S. Fish and Wildlife Service (FWS) provided exceptional hospitality at the Rachel Carson National Wildlife Refuge, Maine, for the 2018 structured decisionmaking workshop, which included participants from six additional national wildlife refuges. Nathan Bush of the FWS generated the mapping data used in this report, and Jackie Olson of the U.S. Geological Survey expertly prepared the maps. Technical reviews by Rachel Katz of the FWS and Bill Thompson of the National Park Service greatly improved the quality of this report. 



\section{Contents}

Acknowledgments ……...................................................................................................................

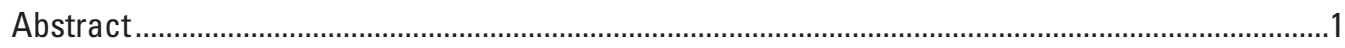

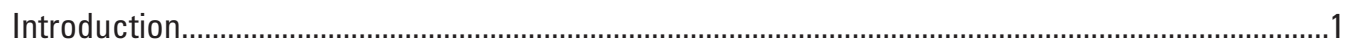

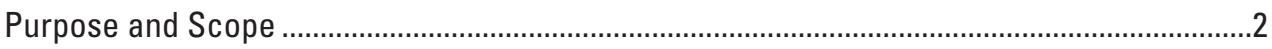

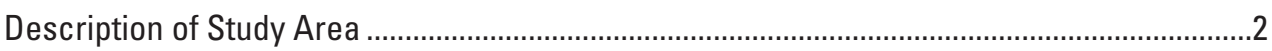

Regional Structured Decision-Making Framework …….........................................................

Application to the Rachel Carson National Wildlife Refuge..........................................................10

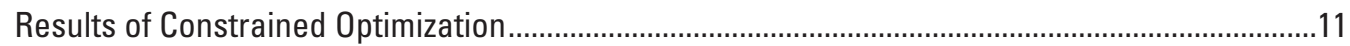

Considerations for Optimizing Salt Marsh Management.................................................................13

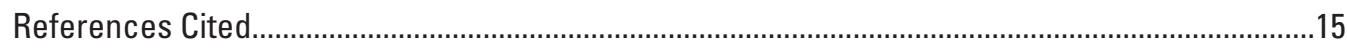

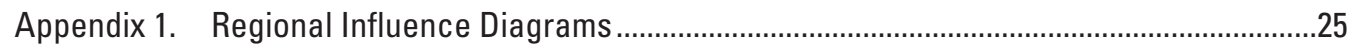

Appendix 2. Utility Functions for the Rachel Carson National Wildlife Refuge .............................32

\section{Figures}

1. Map showing national wildlife refuges and national wildlife refuge complexes of the U.S. Fish and Wildlife Service where salt marsh integrity was assessed from 2012 to 2016 using the regional monitoring protocol ...............................................3

2. Map showing salt marsh management units of the Rachel Carson National Wildlife Refuge in Maine

3. Graph showing predicted total management benefit of various portfolios, expressed as weighted utilities, relative to total cost at the Rachel Carson National Wildlife Refuge in Maine

4. Bar chart of predicted management benefit of portfolio 7 in comparison to the management benefit from the baseline "no-action" portfolio at the Rachel Carson National Wildlife Refuge in Maine

\section{Tables}

1. Objectives hierarchy for salt marsh management decision problems

2. Participants in the workshop convened at the Rachel Carson National Wildlife Refuge, Maine, to apply a regional framework for optimizing salt marsh management decisions to six national wildlife refuges in January 2018.

3. Possible management actions for achieving objectives within seven marsh management units at the Rachel Carson National Wildlife Refuge, Maine, estimated costs over 5 years, and predicted outcomes expressed relative to performance metrics..

4. Normalized predicted outcomes and estimated total management benefits of possible management actions within seven marsh management units at the Rachel Carson National Wildlife Refuge, Maine.

5. Actions included in various management portfolios to maximize the total management benefits subject to increasing cost constraints at the Rachel Carson National Wildlife Refuge, Maine 


\section{Conversion Factors}

International System of Units to U.S. customary units

\begin{tabular}{llll}
\hline & Multiply & \multicolumn{1}{c}{ By } & To obtain \\
\hline meter $(\mathrm{m})$ & 3.281 & foot $(\mathrm{ft})$ & \\
kilometer $(\mathrm{km})$ & 0.6214 & mile $(\mathrm{mi})$ & \\
square meter $\left(\mathrm{m}^{2}\right)$ & 0.0002471 & acre & \\
hectare $(\mathrm{ha})$ & 2.471 & acre & \\
\hline
\end{tabular}

\section{Datums}

Vertical coordinate information is referenced to the North American Vertical Datum of 1988 (NAVD 88).

Horizontal coordinate information is referenced to the North American Datum of 1983 (NAD 83).

Elevation, as used in this report, refers to distance above the vertical datum.

\section{Abbreviations}

FWS U.S. Fish and Wildlife Service

NWR national wildlife refuge

NWRS National Wildlife Refuge System

USGS U.S. Geological Survey 


\title{
Optimization of Salt Marsh Management at the Rachel Carson National Wildlife Refuge, Maine, Through Use of Structured Decision Making
}

\author{
By Hilary A. Neckles, ${ }^{1}$ James E. Lyons, ${ }^{1}$ Jessica L. Nagel,, Susan C. Adamowicz, ${ }^{2}$ Toni Mikula, ${ }^{2}$ \\ Kathleen M. O'Brien, ${ }^{2}$ Bri Benvenuti, ${ }^{2}$ and Ryan Kleinert ${ }^{2}$
}

\section{Abstract}

Structured decision making is a systematic, transparent process for improving the quality of complex decisions by identifying measurable management objectives and feasible management actions; predicting the potential consequences of management actions relative to the stated objectives; and selecting a course of action that maximizes the total benefit achieved and balances tradeoffs among objectives. The U.S. Geological Survey, in cooperation with the U.S. Fish and Wildlife Service, applied an existing, regional framework for structured decision making to develop an example of a prototype tool for optimizing tidal marsh management decisions for selected marsh management units at the Rachel Carson National Wildlife Refuge in Maine. The goal was to create a prototype that could be available for future implementation. Refuge biologists, refuge managers, and research scientists identified multiple potential management actions to improve the ecological integrity of seven marsh management units within the refuge and estimated the outcomes of each action in terms of regional performance metrics associated with each management objective. Value functions previously developed at the regional level were used to transform metric scores to a common utility scale, and utilities were summed to produce a single score representing the total management benefit that could be accrued from each potential management action. Constrained optimization was used to identify the set of management actions, one per marsh management unit, that could maximize total management benefits at different cost constraints at the refuge scale.

Management costs were estimated using limited available information, and estimated costs of individual management actions reflected relative differences among actions rather than actual expected expenditures. Results from this prototype showed how, for the objectives, actions, and estimated outcomes used for this example, total management benefits may increase consistently up to a certain estimated cost, and may

${ }^{1}$ U.S. Geological Survey.

${ }^{2}$ U.S. Fish and Wildlife Service. continue to increase, at a lower rate, with further expenditures. Potential management actions in optimal portfolios at moderate total estimated costs included breaching or removing dikes, roads, or embankments; planting Spartina alterniflora (smooth cordgrass); and digging runnels, or shallow creeks, on the marsh platform to improve surface-water drainage. Potential management actions in optimal portfolios at high estimated costs (for example, up to $\$ 550,000$ ) included breaching embankments to restore tidal exchange followed by planting salt marsh vegetation. The potential management benefits were derived from predicted increases in the numbers of tidal marsh obligate birds and spiders (as an indicator of trophic health), and expected improvement in the capacity of marsh elevation to keep pace with sea-level rise and reduced duration of marsh-surface inundation. The prototype presented here does not resolve current management decisions; rather, it provides a framework for decision making at the Rachel Carson National Wildlife Refuge that can be updated for implementation as new data and information become available. Insights from this process may also be useful to inform future habitat management planning at the refuges.

\section{Introduction}

The National Wildlife Refuge System (NWRS) protects extensive salt marsh acreage in the northeastern United States. Much of this habitat has been degraded by a succession of human activities since the time of European settlement (Gedan and others, 2009), and accelerated rates of sea-level rise exacerbate these effects (Gedan and others, 2011; Kirwan and Megonigal, 2013). Therefore, strategies to restore and enhance the ecological integrity of national wildlife refuge (NWR) salt marshes are regularly considered. Management may include such activities as reestablishing natural hydrology, augmenting or excavating sediments to restore marsh elevation, controlling invasive species, planting native vegetation, minimizing shoreline erosion, and remediating contaminant problems. Uncertainty stemming from incomplete knowledge of system status and imperfect understanding of ecosystem dynamics 
commonly hinders management predictions and selection of the most effective management options. Consequently, tools for identifying appropriate assessment variables and evaluating tradeoffs among management objectives are valuable to inform marsh management decisions.

Structured decision making is a systematic approach to improving the quality of complex decisions that integrates assessment metrics into the decision process (Gregory and Keeney, 2002). This approach involves identifying measurable management objectives and potential management actions, predicting management outcomes, and evaluating tradeoffs to choose a preferred alternative. From 2008 to 2012, the U.S. Geological Survey (USGS) and U.S. Fish and Wildlife Service (FWS) used structured decision making to develop a framework for optimizing management decisions for NWR salt marshes in the FWS Northeast Region (that is, salt marshes in the coastal region from Maine through Virginia). The structured decision-making steps were applied through successive "rapid prototyping" workshops, an iterative process in which relatively short periods of time are invested to continually improve the decision structure (Blomquist and others, 2010; Garrard and others, 2017). The decision framework includes regional management objectives addressing critical components of salt marsh ecosystems, and associated performance metrics for determining whether objectives are achieved (Neckles and others, 2015). The regional objectives structure served as the foundation for a consistent protocol for monitoring salt marsh integrity at these northeastern coastal refuges, in which the monitoring variables are linked explicitly to management goals (Neckles and others, 2013). From 2012 to 2016, this protocol was used by the FWS to conduct a baseline assessment of salt marsh integrity at all 17 refuges or refuge complexes in the FWS Northeast Region with salt marsh habitat (fig. 1).

The Rachel Carson National Wildlife Refuge protects about 923 hectares of salt marsh along 80 kilometers of the southern Maine coast (fig. $2 A-D$ ). Spanning 12 different estuaries, the salt marsh in the refuge provides critical nesting and wintering habitat for birds of highest conservation priority, including Ammodramus caudacutus (saltmarsh sparrows) and Anas rubripes (American black ducks), in the New England and mid-Atlantic coast bird conservation region of the U.S. North American Bird Conservation Initiative (FWS, 2007; Steinkamp, 2008; National Audubon Society, undated; U.S. North American Bird Conservation Initiative, 2020). The salt marsh also provides important foraging habitat for wading birds, such as Ardea alba (great egret) and Egretta thula (snowy egret), during breeding and migratory seasons. The primary concerns for salt-marsh integrity at this refuge are marsh degradation associated with historic hydrologic alterations, and marsh submergence and erosion associated with rising sea level (FWS, 2007; Adamowicz and others, 2020). Salt-marsh management goals set by the FWS for the refuge focus on protecting and restoring critical habitat for breeding, migrating, and wintering birds of conservation concern. The goal of this study was to show how the regional structured decision-making framework could be used to help prioritize future salt marsh management options for the refuge.

\section{Purpose and Scope}

This report describes an example of applying the regional structured decision-making framework (Neckles and others, 2015) to a selection of marsh management units in the Rachel Carson National Wildlife Refuge. The purpose of this example was not to resolve current management decisions, but rather to provide a refuge-specific prototype for future implementation. For this example, the regional framework was parameterized to local conditions through rapid prototyping, producing a decision model for the refuge that can be updated easily as relevant data and information become available. Included in this example are a suite of potential management actions to achieve objectives in seven marsh management units at the refuge, estimated costs for implementing each potential action, predictions for the outcome of each management action relative to individual management objectives, and results of constrained optimization to maximize management benefits subject to cost constraints. Management costs were estimated using limited available information, and estimated costs for individual management actions reflected relative differences among actions rather than expected actual expenditures. Such a decision structure can be used to understand how specific actions may contribute to achieving management objectives and identify an optimum combination of actions, or "management portfolio," to maximize management benefits at the refuge scale for a range of potential budgets. The prototype presented here provides an example framework for continually improving the quality of complex management decisions at the Rachel Carson National Wildlife Refuge.

\section{Description of Study Area}

Salt marsh habitat at the Rachel Carson National Wildlife Refuge is divided into 23 marsh management units. Seven of these units were selected for this prototype and are the subject of this report: Biddeford Pool marsh management unit, in Biddeford, Maine (fig. 2B); Granite Point marsh management unit, at the mouth of the Little River estuary on the border of Biddeford and Kennebunkport, Maine (fig. 2B); Marshall Point marsh management unit, within the Sampson Cove estuary system in Kennebunkport (fig. 2B); Furbish, Bourne, and Moody marsh management units, within the Ogunquit River estuary system in Wells, Maine (fig. 2C); and Brave Boat marsh management unit, within the Brave Boat Harbor estuary system on Cutts Island, Maine (fig. 2D). All of the marsh management units contain low to moderate density of ditching from historic salt hay farming and mosquito control efforts, and portions of the Biddeford Pool, Marshall Point, Moody, and Brave Boat marsh management units have remnants of ditch plugs that were installed around 2000 in attempt 


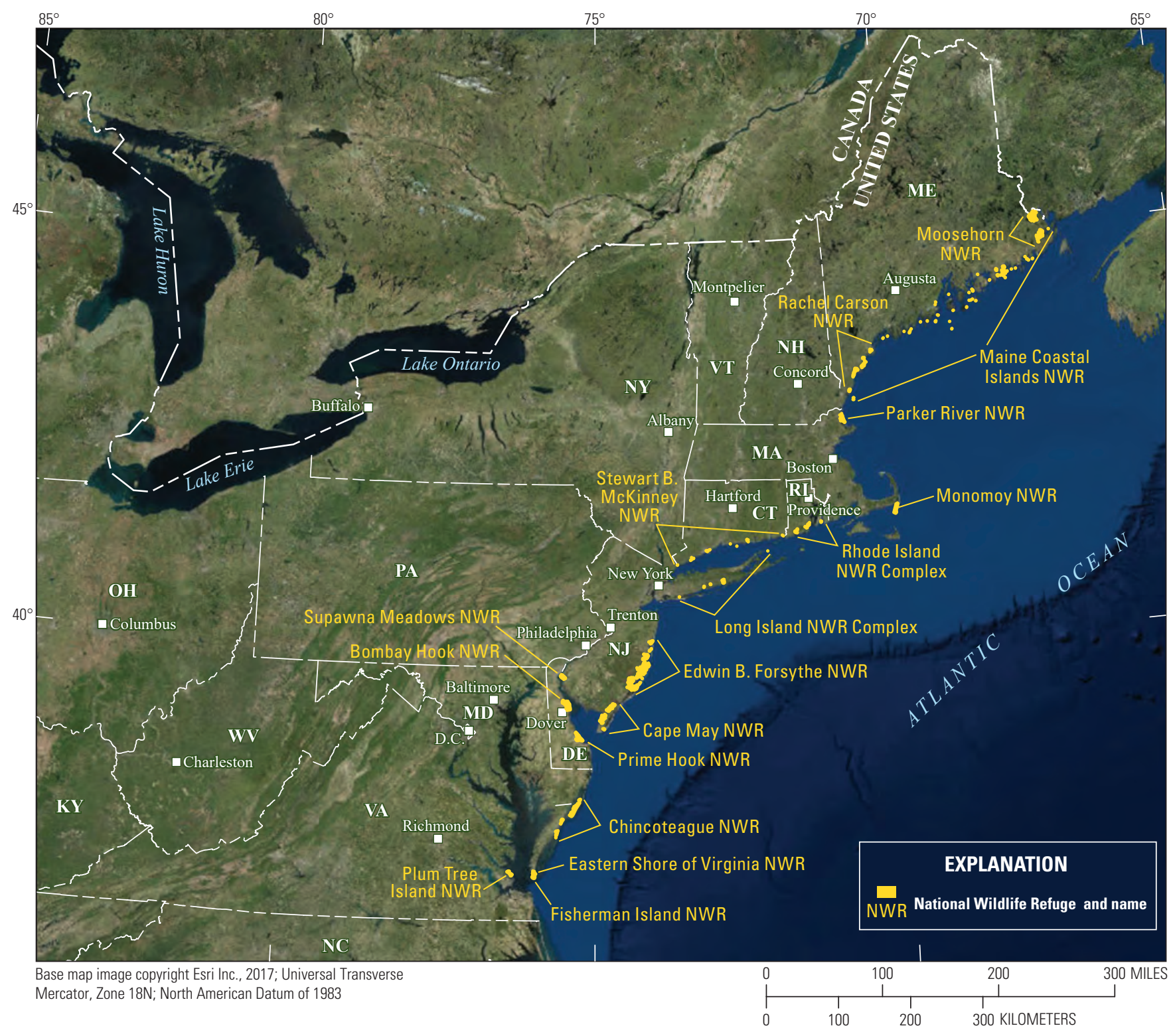

Figure 1. Map showing national wildlife refuges and national wildlife refuge complexes of the U.S. Fish and Wildlife Service where salt marsh integrity was assessed from 2012 to 2016 using the regional monitoring protocol. 
$\boldsymbol{A}$

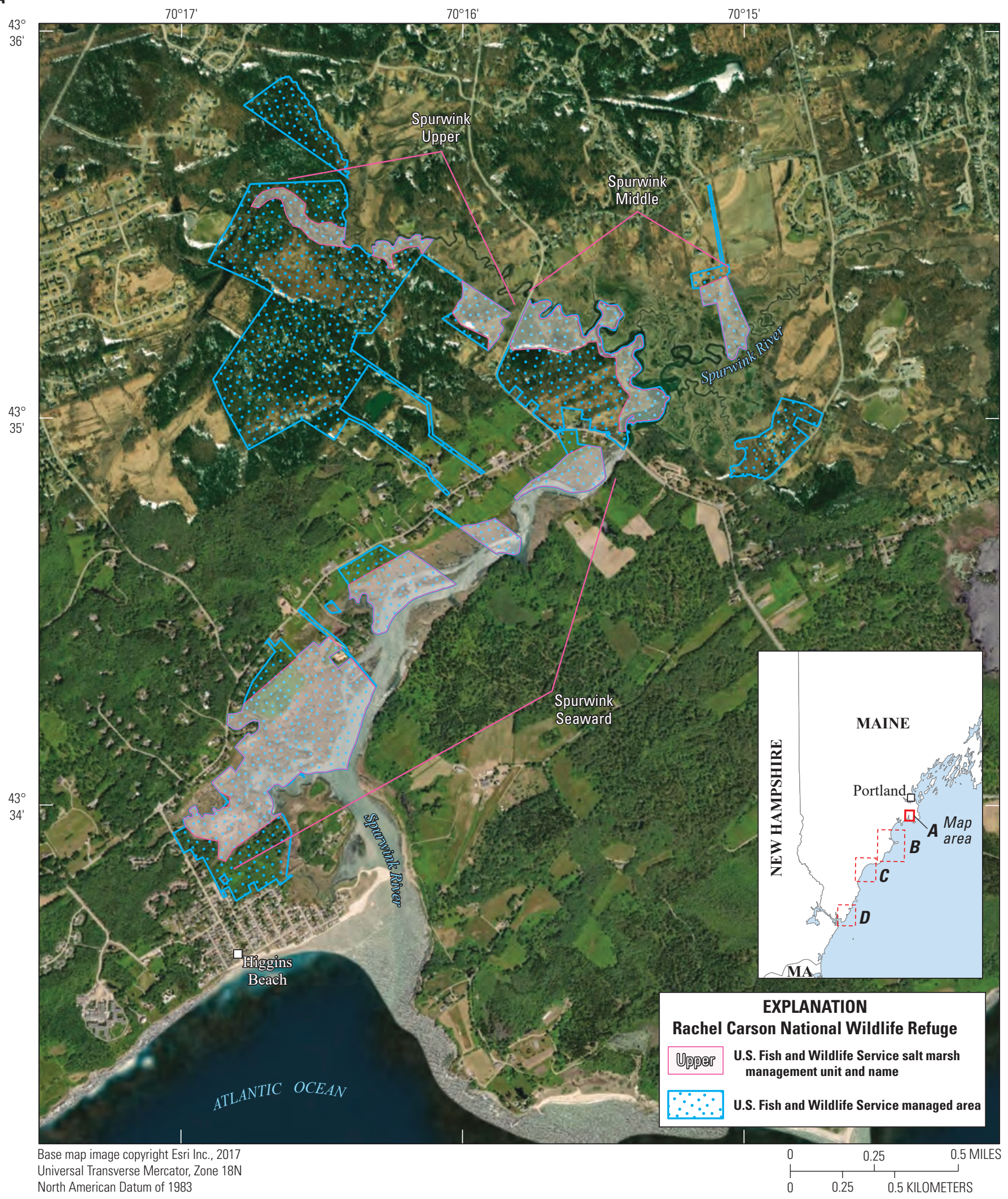

Figure 2. Map showing salt marsh management units at the $A$, northern; $B$, north central; $C$, south central; and $D$, southern parts of Rachel Carson National Wildlife Refuge in Maine. U.S. Fish and Wildlife Service managed areas shown for reference. 
B

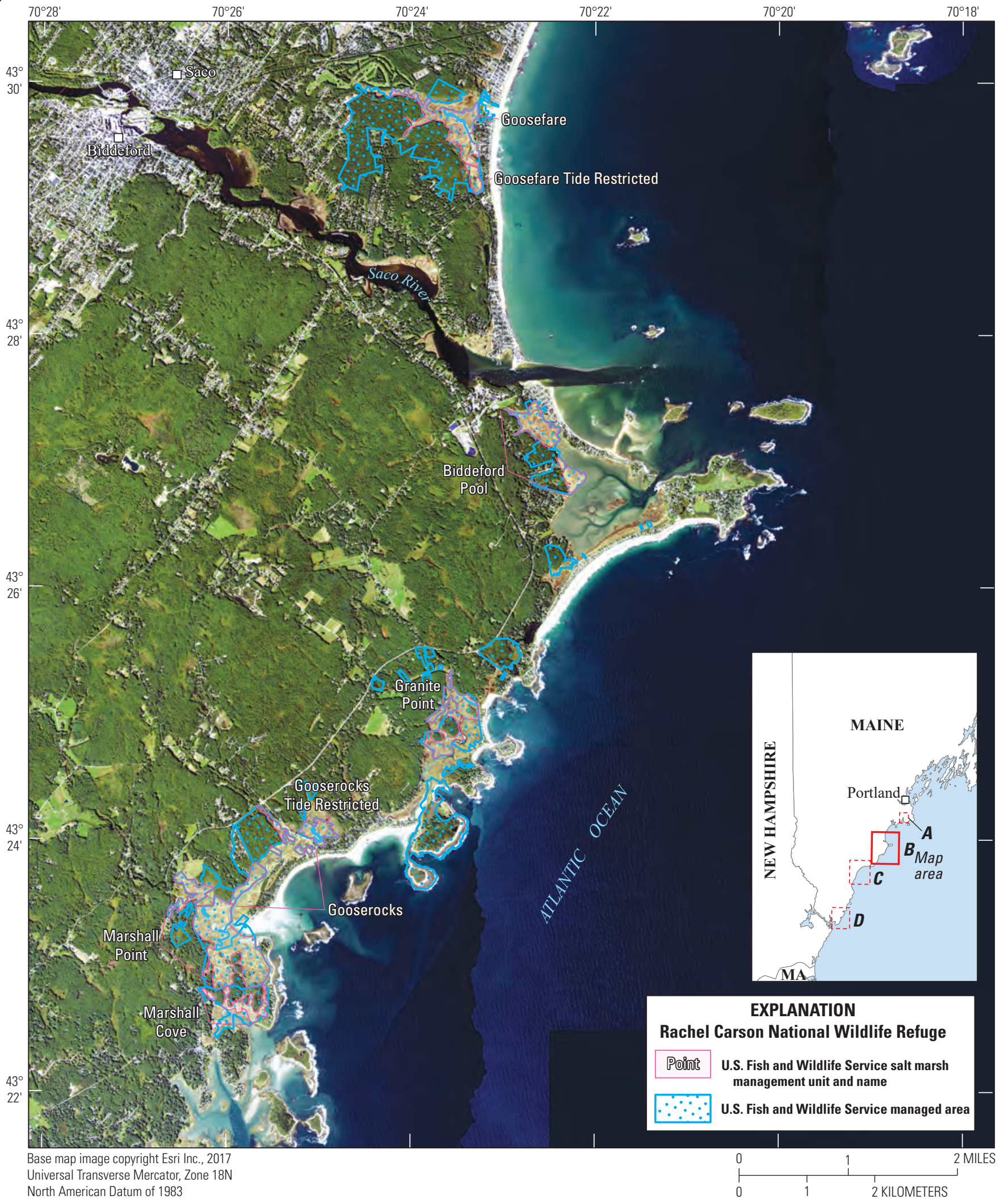

Figure 2.-Continued 
c

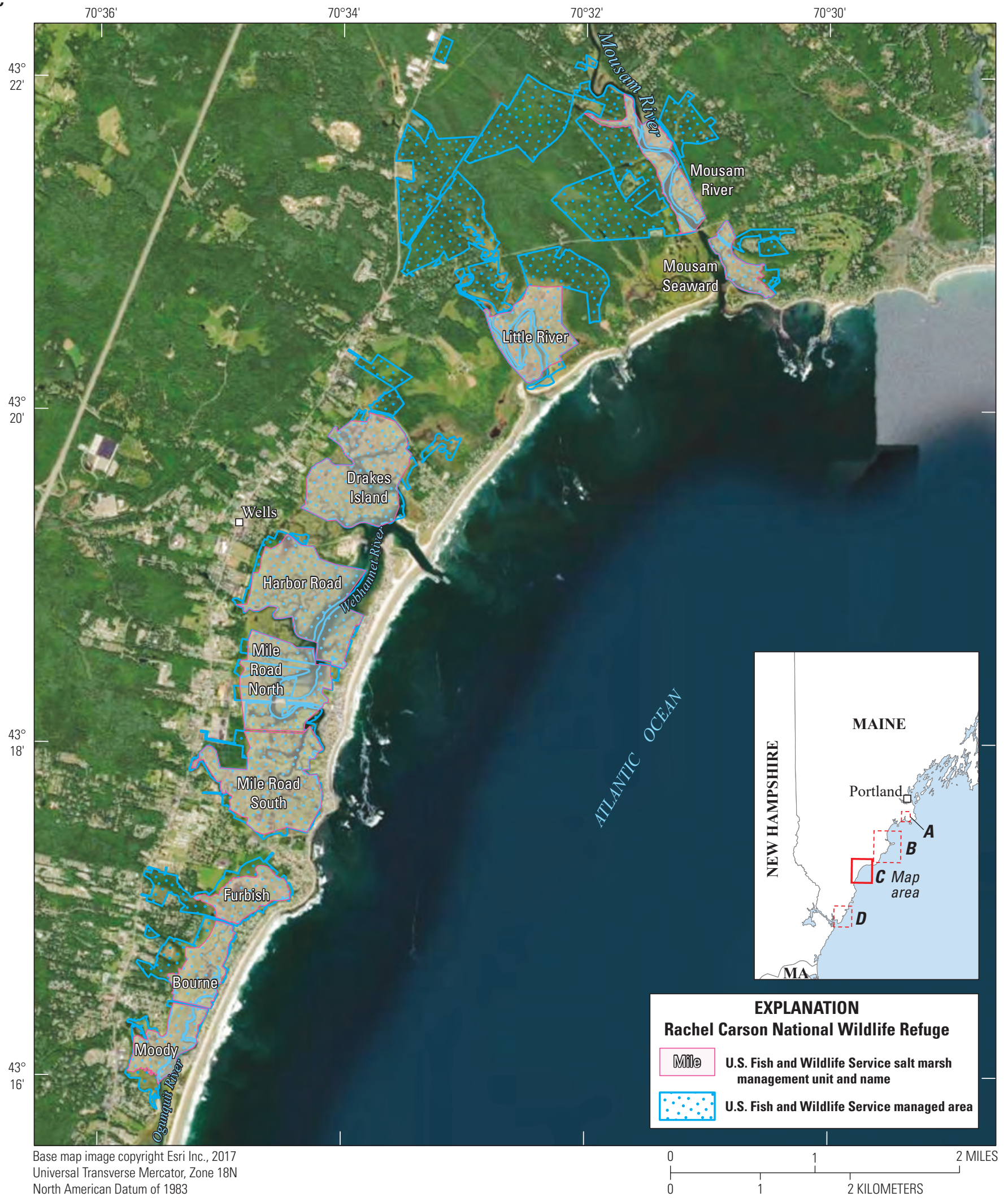

Figure 2.-Continued 
D

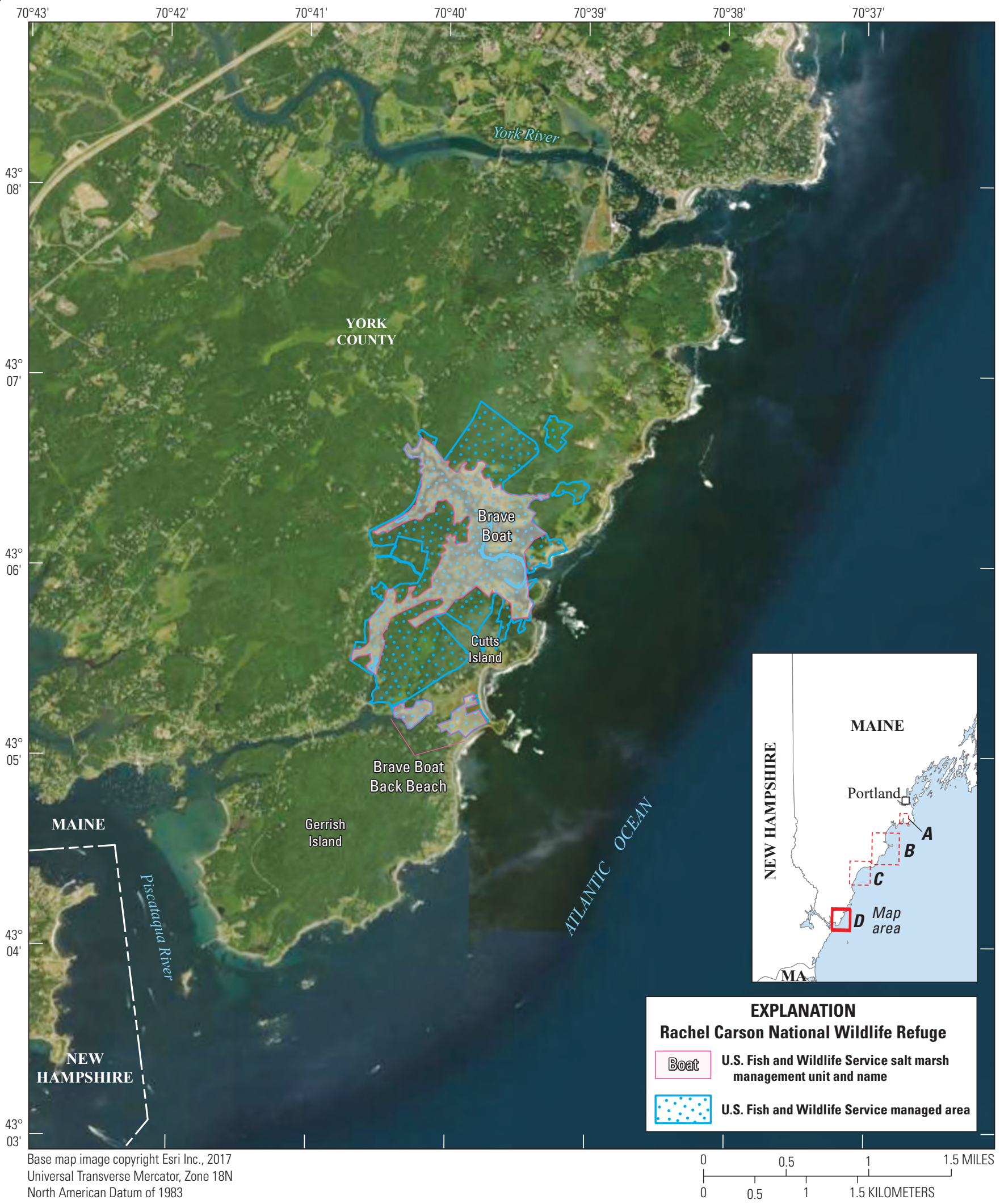

Figure 2.-Continued 
to increase migratory bird habitat. Roads and homes prevent marsh deposition of overwash sediments from the ocean front dune, and at the time of the baseline assessment, embankments or roads restricted tidal exchange within all of the marsh management units selected for this prototype except Granite Point. The majority of land (66-90 percent) within 1 kilometer of most of the marsh management units is categorized under natural land uses (land classified by the 2011 National Land Cover Database as categories other than agricultural or developed; Multi-Resolution Land Characteristics Consortium, 2020). A smaller proportion of land within 1 kilometer of the Furbish, Bourne, and Moody marsh management units is classified as natural (45-50 percent) on account of dense beachfront development shoreward of these salt marshes. During 2012-16, average salt marsh surface-water salinities in the summer ranged from about 26 to 33 parts per thousand (polyhaline to euhaline as defined by Cowardin and others, 1979) within the marsh management units (FWS, 2016).

\section{Regional Structured Decision-Making Framework}

A regional framework for assessing and managing salt marsh integrity at northeastern NWRs was developed through collaborative efforts of FWS regional and refuge managers and biologists, salt marsh research scientists, and structured decision-making experts. This process followed the discrete steps outlined by Hammond and others (1999) and Gregory and Keeney (2002):

1. Clarify the temporal and spatial scope of the management decision.

2. Define objectives and performance measures to evaluate whether objectives are achieved.

3. Develop alternative management actions for achieving objectives.

4. Estimate the consequences or likely outcomes of management actions in terms of the performance measures.

5. Evaluate the tradeoffs inherent in potential alternatives and select the optimum alternatives to maximize management benefits.

This sequence of steps was applied through successive workshops to refine the decision structure and incorporate newly available information. Initial development of the structured decision-making framework occurred during a week-long workshop in 2008 to define the decision problem, specify management objectives, and explore strategies available to restore and enhance salt marsh integrity. During 2008 and
2009, workshop results were used to guide field tests of salt marsh monitoring variables (Neckles and others, 2013). Subsequently, in 2012, data and insights gained from these field tests were used in a two-part workshop to refine management objectives and develop the means for evaluating management outcomes (Neckles and others, 2015).

From the outset, FWS goals included development of an approach for consistent assessment of salt marsh integrity across all northeastern NWRs (fig. 1). Within this regional context, staff at a given refuge must periodically determine the best approaches for managing salt marshes to maximize habitat value while considering financial and other constraints. The salt marsh decision problem was thus defined as applying to individual NWRs over a 5-year planning horizon. The objectives for complex decisions can be organized into a hierarchy to help clarify what is most important to decision makers (Gregory and others, 2012). The hierarchy of objectives for salt marsh management decisions (table 1) was based explicitly on the conservation mission of the NWRS, which is upheld through management to "ensure that the biological integrity, diversity, and environmental health of the System are maintained for the benefit of present and future generations of Americans," as mandated in the National Wildlife Refuge System Improvement Act of 1997 (16 U.S.C. §668dd note). Two fundamental objectives, or the overall goals for salt marsh management decisions, were drawn from this policy to maximize (1) biological integrity and diversity, and (2) environmental health, of salt marsh ecosystems. Participants in the regional prototyping workshops deconstructed these overall goals further into lower-level objectives relating to salt marsh structure and function and identified performance metrics to evaluate whether objectives are achieved (table 1). In addition, performance metrics were weighted to reflect the relative importance of each objective (Neckles and others, 2015).

The hierarchy of objectives for salt marsh management (table 1) provides the foundation for identifying possible management actions at individual NWRs and predicting management outcomes. Workshop participants developed preliminary influence diagrams (app. 1), or conceptual models relating management actions to responses by each performance metric (Conroy and Peterson, 2013), to guide this process. To allow metric responses to be aggregated into a single, overall performance score, participants also defined value functions relating salt marsh integrity metric scores to perceived management benefit on a common, unitless "utility" scale (Keeney and Raiffa, 1993). Stakeholder elicitation was used to determine the form of each value function relating the original metric scale to the utility scale, ranging from 0 , representing the lowest management benefit, to 1 , representing the highest benefit (app. 2). Neckles and others (2015) provided details regarding development of the structured decision-making framework and a case-study application to Prime Hook National Wildlife Refuge in Delaware. 
Table 1. Objectives hierarchy for salt marsh management decision problems.

[Two fundamental objectives (overall goals of the decision problem) draw directly from U.S. Fish and Wildlife Service (FWS) National Wildlife Refuge System policy to maintain, restore, and enhance biological integrity, diversity, and environmental health within the refuge. These are broken down into lower level objectives focused on specific aspects of marsh structure and function. Values in parentheses are weights assigned to objectives, reflecting their relative importance. Weights on any branch of the hierarchy (that is, objectives that are at the same level of the hierarchy under a fundamental objective) sum to one. The weight for each metric is the product of the weights from each level of the hierarchy leading to that metric. See also Neckles and others (2015).NA, not applicable]

\begin{tabular}{|c|c|c|}
\hline FWS regional objective & Performance metric & Unit of measurement \\
\hline \multicolumn{3}{|c|}{ Maximize biological integrity and diversity ${ }^{1}(0.5)$} \\
\hline Maximize cover of native vegetation $(0.24)$ & Cover of native vegetation & Percent \\
\hline Maximize nekton abundance $(0.50)$ & Native nekton density & Number per square meter \\
\hline $\begin{array}{l}\text { Maximize use by nonbreeding wetland birds } \\
(0.20)\end{array}$ & $\begin{array}{l}\text { Abundance of American black duck as indicator } \\
\text { species }\end{array}$ & $\begin{array}{l}\text { Relative abundance for refuge during } \\
\text { wintering waterfowl season (low, } \\
\text { medium, high) }\end{array}$ \\
\hline Maintain natural hydrology $(0.44)$ : & NA & NA \\
\hline Maintain natural flooding regime $(0.50)$ & $\begin{array}{l}\text { Percent of time marsh surface is flooded relative } \\
\text { to ideal reference system }\end{array}$ & $\begin{array}{l}\text { Absolute deviation from reference in } \\
\text { percentage points }\end{array}$ \\
\hline Maintain natural salinity $(0.50)$ & $\begin{array}{l}\text { Surface-water salinity relative to ideal reference } \\
\text { system }\end{array}$ & $\begin{array}{l}\text { Absolute deviation from reference in } \\
\text { parts per thousand }\end{array}$ \\
\hline $\begin{array}{l}\text { Maintain the extent of the marsh platform } \\
(0.44)\end{array}$ & $\begin{array}{l}\text { Change in marsh surface elevation relative to } \\
\text { sea-level rise }\end{array}$ & $\begin{array}{l}0=\text { Change in elevation is less than } \\
\text { amount of sea-level rise; } 1=\text { change } \\
\text { in elevation greater than or equal to } \\
\text { amount of sea-level rise }\end{array}$ \\
\hline Minimize use of herbicides $(0.12)$ & Rate of application & $\begin{array}{l}0=\text { No herbicide applied; } 1=\text { herbicide } \\
\text { applied }\end{array}$ \\
\hline
\end{tabular}

${ }^{1}$ Fundamental objectives of salt marsh management decisions.

${ }^{2}$ Species composition adjusted from regional performance metric to reflect bird geographic ranges relative to the Rachel Carson National Wildlife Refuge. "Unknown sharptailed sparrow" includes saltmarsh sparrow, Nelson's sparrow, and hybrids between the two species.

${ }^{3}$ Relative abundance based on local knowledge. 


\section{Application to the Rachel Carson National Wildlife Refuge}

In January 2018, FWS regional biologists, biologists and managers from seven northeastern NWR administrative units and USGS and Yale University research scientists (table 2) participated in a 1.5-day rapid-prototyping workshop to apply the regional structured decision-making framework to the Maine Coastal Islands, Monomoy, Moosehorn, Parker River, Rachel Carson, and Stewart B. McKinney National Wildlife Refuges. Participants worked within refuge-specific small groups to focus on management issues at individual refuges. Plenary discussions of common patterns of salt marsh degradation, potential management strategies, and mechanisms of ecosystem response offered additional insights to enhance refuge-specific discussions.

Participants identified a range of possible management actions for achieving objectives within each marsh management unit at the Rachel Carson National Wildlife Refuge

Table 2. Participants in the workshop convened at the Rachel Carson National Wildlife Refuge, Maine, to apply a regional framework for optimizing salt marsh management decisions to six national wildlife refuges in January 2018.

[FWS, U.S. Fish and Wildlife Service; NWR, National Wildlife Refuge; USGS, U.S. Geological Survey]

\begin{tabular}{ll}
\hline \multicolumn{1}{c}{ Affiliation } & \multicolumn{1}{c}{ Participant } \\
\hline Maine Coastal Islands NWR & Sara Williams \\
Monomoy NWR & Matthew Hillman \\
Moosehorn NWR & Maurice Mills \\
Moosehorn NWR & Keith Ramos \\
Moosehorn NWR & Ray Brown \\
Parker River NWR & Nancy Pau \\
Parker River NWR & Bill Peterson \\
Rachel Carson NWR & Kathleen O'Brien \\
Rachel Carson NWR & Ryan Kleinert \\
Rachel Carson NWR & Bri Benvenuti \\
Stewart B. McKinney NWR & Richard Potvin \\
Stewart B. McKinney NWR & Kristina Vagos \\
\hline
\end{tabular}

FWS regional experts

\begin{tabular}{|c|c|}
\hline Northeast Regional Office & Rachel Katz \\
\hline Northeast Regional Office & Troy Wilson \\
\hline Rachel Carson NWR & Susan Adamowicz \\
\hline \multicolumn{2}{|l|}{ Research scientists } \\
\hline USGS Eastern Ecological Science Center & James Lyons \\
\hline USGS Eastern Ecological Science Center & Hilary Neckles \\
\hline $\begin{array}{l}\text { Yale University School of Forestry and } \\
\text { Environmental Studies }\end{array}$ & Laurel Low \\
\hline
\end{tabular}

and estimated the total cost of implementation over a 5-year period; the specific years of implementation were not identified in this prototype. True costs were unavailable; rather, management costs were estimated to reflect their relative magnitudes across a range of management actions. Potential actions to enhance salt marsh integrity included restoring hydrologic connections, enhancing drainage from certain areas of the marsh platform, or altering marsh elevation or vegetation succession (table 3 , in back of report). Participants predicted the outcomes of each management action 5 years after initial implementation in terms of salt marsh integrity performance metrics. For most metrics, baseline conditions within each unit measured during the 2012-16 salt marsh integrity assessment (FWS, 2016) were used to predict the outcomes of a "no-action" alternative. Baseline conditions were estimated by using expert judgement for three metrics that lacked assessment data (abundance of American black ducks, density of spiders, change in marsh surface elevation relative to sea-level rise). Regional influence diagrams relating management strategies to outcomes aided in predicting consequences of management actions (app. 1). Although the influence diagrams incorporated the potential effects of stochastic processes, including weather, sea-level rise, herbivory, contaminant inputs, and disease, on management outcomes, no attempt was made to quantify these sources of uncertainty during rapid prototyping. Management predictions also inherently included considerable uncertainty surrounding the complex interactions among controlling factors and salt marsh ecosystem components.

Following the workshop, the potential management benefit of each salt marsh integrity performance metric was calculated by converting salt marsh integrity metric scores (table 3, workshop output) to weighted utilities (table 4, in back of report) using regional value functions (app. 2). Weighted utilities were summed across all salt marsh integrity metrics for each action; this overall utility therefore represented the total management benefit, across all objectives, expected to accrue from a given management action (table 4). Constrained optimization (Conroy and Peterson, 2013) was used to find the management portfolio (the combination of actions, one action per marsh management unit) that maximizes the total management benefit across all units under varying cost scenarios for the entire the refuge. Constrained optimization using integer linear programming was implemented in the Solver tool in Microsoft Excel (Kirkwood, 1997).

Budget constraints were increased in $\$ 5,000$ increments up to $\$ 10,000$; in $\$ 10,000$ increments up to $\$ 50,000$; in $\$ 25,000$ increments up to $\$ 100,000$; in $\$ 50,000$ increments up to $\$ 300,000$; in $\$ 100,000$ increments up to $\$ 1$ million; and in $\$ 500,000$ increments thereafter. The upper limit to potential costs was not determined in advance; rather, it reflected the total estimated costs of the proposed management actions. A cost-benefit plot of the portfolios identified through the optimization analysis was used to identify the efficient frontier for resource allocation (Keeney and Raiffa, 1993), which is the set of portfolios that are not dominated by other portfolios at similar costs (or the set of portfolios with maximum total benefit 
for a similar cost). The cost-benefit plot also revealed the cost above which further expenditures would yield diminishing returns on investment. To exemplify use of the decisionmaking framework to understand how a given portfolio could affect specific management objectives, the refuge-scale management benefits for individual performance metrics were compared between one optimal portfolio and those predicted with no management action taken.

\section{Results of Constrained Optimization}

Potential management actions identified to possibly improve marsh integrity at selected marsh management units in the Rachel Carson National Wildlife Refuge included restoring natural hydrology and reducing the degree of tidal restriction through various mechanisms, including restoring tidal channels, breaching or removing dikes or embankments, or installing culverts or water control structures. Additional management actions were directed toward building elevation by adding sediment to the marsh surface and creating elevated nesting habitat for marsh birds, and at facilitating marsh migration by acquiring adjacent uplands (table 3 ).
For estimated costs ranging from $\$ 0$ to $\$ 865,000$, the estimated management benefits for individual actions across all metrics, measured as weighted utilities, ranged from 0.497 (for implementing control of Phragmites australis, hereafter referred to as Phragmites, in the Furbish marsh management unit) to 0.963 (for breaching the berm to restore tidal exchange followed by vegetation planting in the Marshall Point marsh management unit), out of a maximum possible total management benefit of 1.0 (tables 3 and 4). In most marsh management units, the alternative with both the lowest management benefit and lowest cost was the "no-action" alternative; however, in the Furbish marsh management unit, controlling Phragmites through herbicide use yielded a lower total management benefit than implementing no management actions.

Constrained optimization was applied to identify the optimal management portfolios over 5 years for a range of total estimated costs to the refuge. As total cost increased from $\$ 0$ (no action in either unit) to about $\$ 565,000$, the total management benefit at the refuge scale increased from 3.972 to 6.226 (a 57-percent increase; table 5) out of a possible maximum of 7.0 (the maximum possible management benefit of 1.0 for any management action, summed across the seven marsh management units). Graphical analysis showed a fairly consistent increase in management benefit as estimated costs increased to

Table 5. Actions included in various management portfolios to maximize the total management benefits subject to increasing cost constraints at the Rachel Carson National Wildlife Refuge, Maine.

[Letter designations for actions refer to specific actions and are listed in table 3 and table 4. Portfolios represent the combination of potential actions, one per marsh management unit, that maximized the total management benefit across all units, subject to a refuge-wide cost constraint. The management actions constituting individual portfolios were selected using constrained optimization. The total cost represents the sum of costs estimated for each action included in the portfolio. The maximum possible total management benefit for the refuge is 7.0 , derived as the maximum possible total management benefit of 1.0 for any management action within one management unit, summed across seven units]

\begin{tabular}{|c|c|c|c|c|c|c|c|c|c|}
\hline \multirow[b]{2}{*}{ Portfolio } & \multicolumn{7}{|c|}{ Marsh management unit } & \multirow{2}{*}{$\begin{array}{l}\text { Total cost } \\
\text { (dollars) }\end{array}$} & \multirow{2}{*}{$\begin{array}{l}\text { Total manage- } \\
\text { ment benefit }\end{array}$} \\
\hline & $\begin{array}{c}\text { Granite } \\
\text { Point }\end{array}$ & $\begin{array}{c}\text { Marshall } \\
\text { Point }\end{array}$ & Furbish & $\begin{array}{c}\text { Brave } \\
\text { Boat }\end{array}$ & Bourne & Moody & $\begin{array}{c}\text { Biddeford } \\
\text { Pool }\end{array}$ & & \\
\hline 1 & A & A & A & A & A & A & A & 0 & 3.972 \\
\hline 2 & A & A & A & B & $\mathrm{F}$ & A & $\mathrm{F}$ & 4,824 & 4.067 \\
\hline 3 & $\mathrm{~F}$ & A & A & B & $\mathrm{F}$ & E & $\mathrm{F}$ & 7,224 & 4.074 \\
\hline 4 & $\mathrm{~F}$ & $\mathrm{C}$ & A & B & $\mathrm{F}$ & E & $\mathrm{F}$ & 13,224 & 4.084 \\
\hline 5 & $\mathrm{~F}$ & $\mathrm{~F}$ & A & B & $\mathrm{F}$ & E & $\mathrm{F}$ & 23,724 & 4.131 \\
\hline 6 & A & $\mathrm{D}$ & A & A & $\mathrm{F}$ & A & $\mathrm{F}$ & 39,504 & 4.515 \\
\hline 7 & $\mathrm{~F}$ & $\mathrm{D}$ & A & B & $\mathrm{F}$ & E & $\mathrm{F}$ & 42,904 & 4.533 \\
\hline 8 & $\mathrm{~F}$ & $\mathrm{D}$ & A & B & $\mathrm{F}$ & $\mathrm{C}$ & $\mathrm{F}$ & 73,404 & 4.798 \\
\hline 9 & $\mathrm{~F}$ & $\mathrm{D}$ & $\mathrm{D}$ & B & $\mathrm{F}$ & $\mathrm{C}$ & $\mathrm{F}$ & 92,904 & 4.846 \\
\hline 10 & $\mathrm{~F}$ & D & A & E & $\mathrm{F}$ & $\mathrm{C}$ & $\mathrm{F}$ & 135,404 & 5.072 \\
\hline 11 & $\mathrm{~F}$ & D & D & E & $\mathrm{F}$ & $\mathrm{C}$ & $\mathrm{F}$ & 154,904 & 5.119 \\
\hline 12 & $\mathrm{~F}$ & D & D & E & $\mathrm{C}$ & $\mathrm{C}$ & F & 249,180 & 5.384 \\
\hline 13 & I & D & D & E & $\mathrm{F}$ & $\mathrm{C}$ & F & 283,504 & 5.426 \\
\hline 14 & I & D & D & E & $\mathrm{C}$ & $\mathrm{C}$ & $\mathrm{F}$ & 377,780 & 5.691 \\
\hline 15 & I & D & $\mathrm{C}$ & E & $\mathrm{F}$ & $\mathrm{C}$ & $\mathrm{C}$ & 470,404 & 5.961 \\
\hline 16 & I & D & $\mathrm{C}$ & E & $\mathrm{C}$ & $\mathrm{C}$ & $\mathrm{C}$ & 564,680 & 6.226 \\
\hline
\end{tabular}


$\$ 43,000$ (fig. 3, portfolio 7). Portfolio 7 represented the turning point in the cost-benefit analysis; as expenditures increased beyond the cost of portfolio 7, total management benefit continued to increase at a lower rate (fig. 3).

Several patterns emerged relative to the potential management actions selected by constrained optimization within the set of portfolios that yielded the greatest total management benefit per unit cost (portfolios 2 through 7, table 5). All of these portfolios included actions to improve hydrologic conditions in multiple marsh management units. In most units, the primary hydrologic restoration that was selected involved breaching or removing dikes, roads, or embankments (Granite Point, Marshall Point, Brave Boat, and Moody marsh management units). In the Biddeford Pool marsh management unit, planting Spartina alterniflora (smooth cordgrass) was selected consistently, and in the Bourne marsh management unit, digging runnels, or shallow creeks, on the marsh platform to improve surface-water drainage was selected consistently. In contrast, some management actions were never included in the portfolios yielding the greatest benefit per cost. For example, creating elevated nesting habitat for marsh birds and applying thin layer deposition were identified as possible management actions in most marsh management units, but were never selected in a management portfolio. No management actions in the Furbish marsh management unit were included in portfolios 2 through 7.
Examination of the refuge-scale metric responses to actions included in portfolio 7, which is the turning point in the cost-benefit plot (fig. 3), revealed how implementation could affect specific management objectives. The actions included were predicted to achieve large gains in the overall management benefits derived from increased density of spiders (as an indicator of trophic health) and the improved capacity of marsh elevation to keep pace with sea-level rise, and modest gains in the benefits derived from increased numbers of tidal marsh obligate birds and reduced duration of flooding (fig. 4). Ecologically, the combination of actions in portfolio 7 may result in an average 18-percent increase in tidal marsh obligate bird counts (averaged across all marsh management units), 48-percent decrease in the deviation of surface flooding from the ideal reference condition, and 614-percent increase in spider density (derived as the average difference between the predicted metric scores for the actions implemented in portfolio 7 and the "no-action" alternative; table 3). Implementation of actions in this portfolio was predicted to improve the capacity for marsh elevation to keep pace with sea-level rise in one marsh management unit. The management benefits predicted for portfolios 2 through 6 , at total costs up to $\$ 39,500$, were derived primarily from expected increases in densities of spiders and numbers of tidal marsh obligate birds (table 3 , table 4).

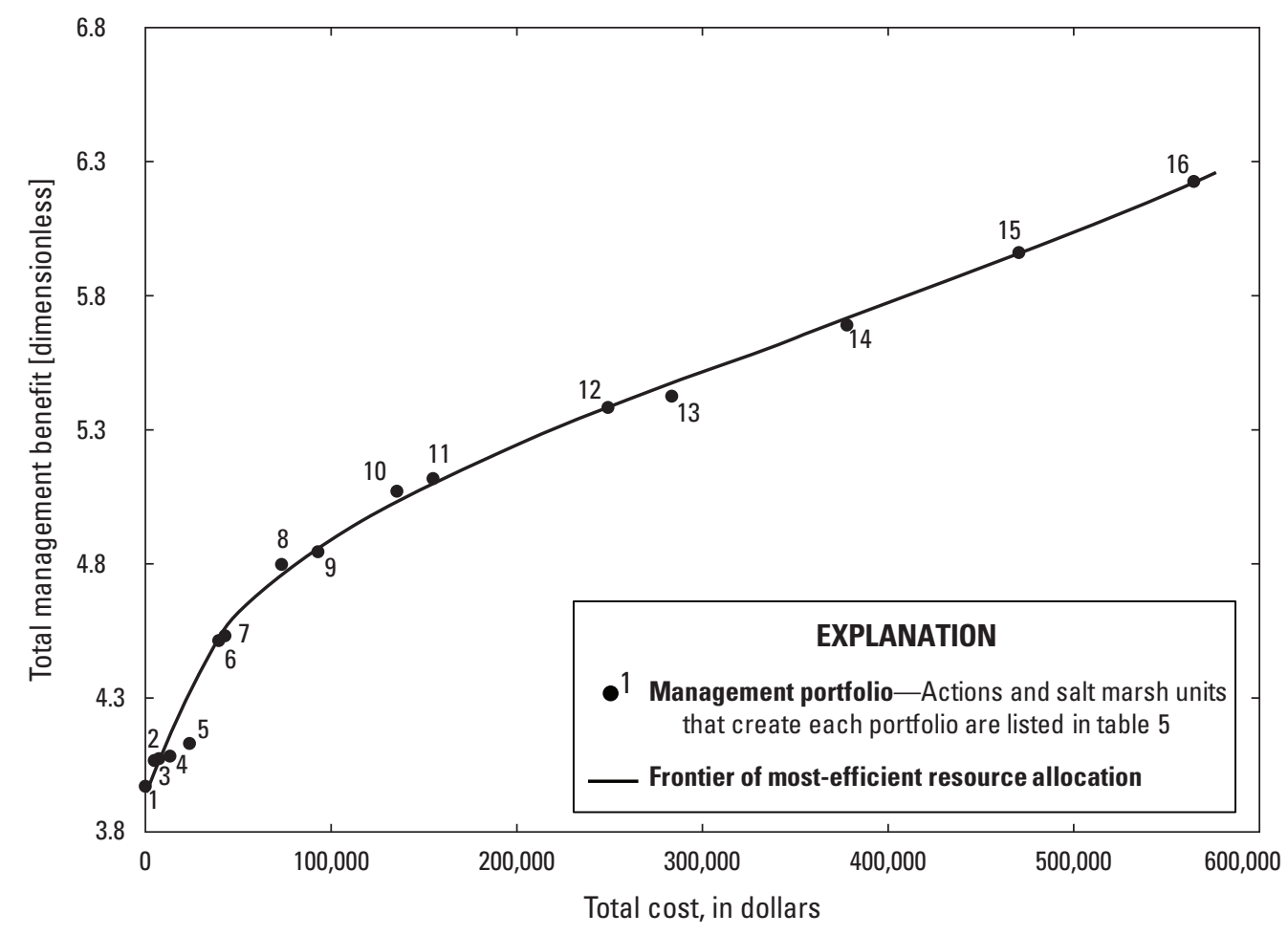

Figure 3. Graph showing predicted total management benefit of various portfolios, expressed as weighted utilities, relative to total cost at the Rachel Carson National Wildlife Refuge in Maine. Each portfolio (dot with number) represents a combination of seven management actions, one per marsh management unit, as identified in table 5 . The line represents the efficient frontier for resource allocation. 


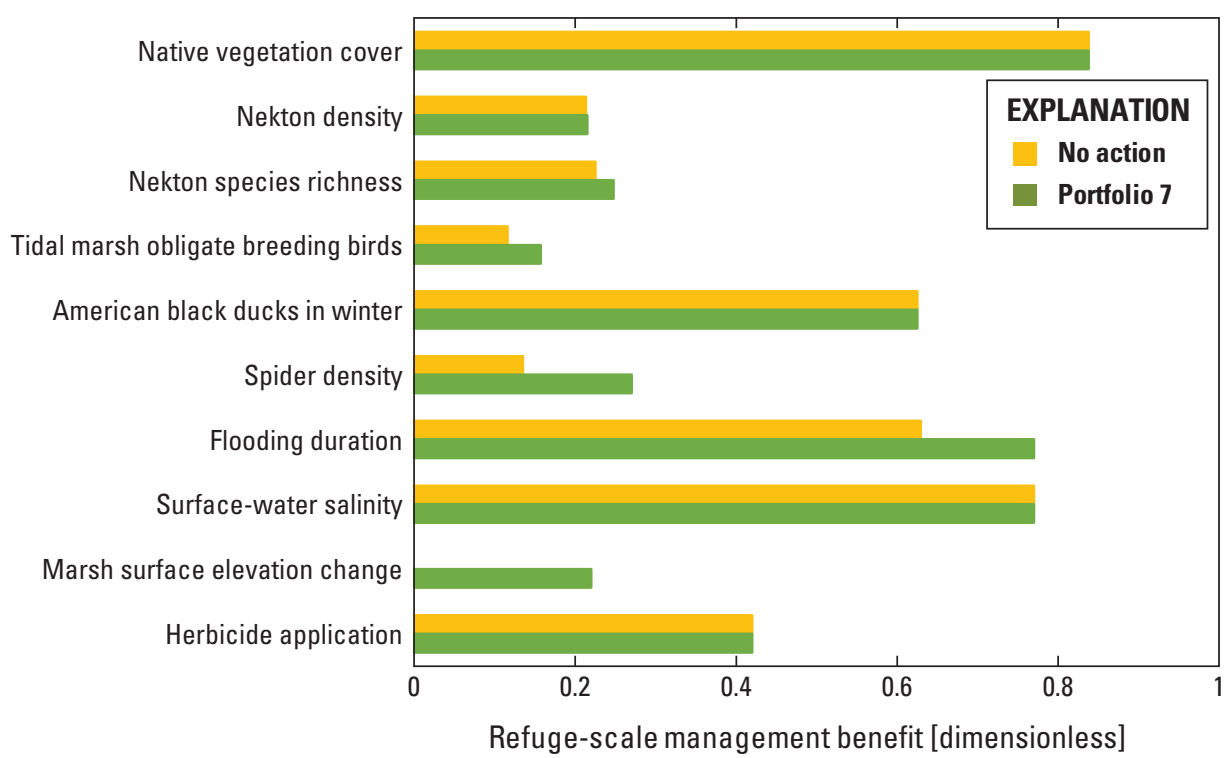

Figure 4. Bar chart showing predicted management benefit at the refuge scale for individual performance metrics, expressed as weighted utilities, resulting from implementation of the management actions included in portfolio 7 , in comparison to the management benefit from the baseline "no-action" portfolio, at the Rachel Carson National Wildlife Refuge in Maine. Baseline ("no action") predicted management benefit for marsh surface elevation change is 0 . The actions included in each portfolio are listed in table 5.

\section{Considerations for Optimizing Salt Marsh Management}

A regional structured decision-making framework for salt marshes in NWRs in the northeastern United States was applied by the USGS, in cooperation with the FWS, to develop a tool for optimizing management decisions at selected marsh management units in the Rachel Carson National Wildlife Refuge. Use of the existing regional framework and a rapidprototyping approach permitted NWR biologists and managers, FWS regional authorities, and research scientists to construct a decision model for the refuge within the confines of a 1.5 -day workshop. This preliminary prototype provides a local framework for decision making while revealing information needs for future implementation. Insights from this process may also be useful to inform future habitat management planning at the refuge.

The suite of potential management actions and predicted outcomes included in this prototype (table 3 ) were based on current understanding of the Rachel Carson National Wildlife Refuge salt marshes and hypothesized process-response pathways (app. 1). Tidal flooding is the predominant physical control on the structure and function of salt marsh ecosystems (Pennings and Bertness, 2001), and there is widespread scientific effort to elucidate how salt marshes may respond to accelerating rates of sea-level rise and management strategies to enhance their sustainability (Kirwan and Megonigal, 2013; Roman, 2017). In particular, many salt marshes throughout the northeastern United States are degraded by roads, dikes, railroads, or other obstructions to tidal flow, and salt marsh restoration focuses frequently on reestablishing tidal flow (Konisky and others, 2006; Roman and Burdick, 2012). In this prototype, actions to partially restore tidal hydrology through breaching dikes and causeways were predicted to improve overall management benefit for a relatively low cost. However, a growing body of literature suggests that removing tidal restrictions may not restore high salt marsh vegetation that provides critical habitat for at-risk species such as saltmarsh sparrows (Elphick and others, 2015). In addition, costs associated with improving the resiliency of the marsh platform in preparation for tidal restoration were not considered in this exercise.

Multiple, interacting factors influence the long-term success of restoration actions in prolonging marsh integrity and improving marsh resilience (Roman, 2017). Future iterations of this decision model can incorporate realistic costs and improved understanding of marsh responses to management actions. In particular, during construction of the regional decision model, a lack of widely available data on rates of vertical marsh growth led to the adoption of a very coarse scale of measurement for change in marsh surface elevation relative to sea-level rise (table 1). From 2013 to 2016, surface elevation tables (Lynch and others, 2015) were installed in each marsh management unit to obtain high-resolution measurements of change in marsh surface elevation. Incorporating this information into subsequent iterations of this structured decisionmaking framework would likely improve predictions related to the potential for marsh surface elevation to keep pace with sea-level rise. 
Results of constrained optimizations (table 5) based on the objectives, management actions, and predicted outcomes included in this prototype identified five areas in which to improve the utility of the prototype for refuge decision making. First, various management actions are used in the northeastern United States in attempt to build the resilience of salt marshes threatened by accelerated sea-level rise and subsequent inundation. Thin-layer deposition of sediments to raise marsh elevation is increasingly proposed to enhance salt marsh sustainability (Wigand and others, 2017), but this prototype suggests sediment enhancement may be cost prohibitive for widespread implementation at the Rachel Carson National Wildlife Refuge and that additional actions may be necessary to achieve the best possible outcome. Alternative options to reduce the depth and duration of surface flooding, such as digging runnels to improve surface drainage, could be more feasible. However, salt marsh response to these management actions may depend on site-specific factors (Wigand and others, 2017). At Rachel Carson National Wildlife Refuge, although runnel creation was predicted to improve surface drainage of the Bourne marsh management unit substantially, runnel creation was not expected to yield significant increases in total management benefit in the Furbish marsh management unit, where baseline conditions indicated that the duration of surface flooding was already within 10 percent of the desired condition (table 3, table 4). By revealing how individual management actions contribute to total management benefit, this prototype offers insight into potential factors influencing the achievement of objectives across different marsh management units and where managers may want to consider additional options to enhance marsh resilience.

Second, constructing microtopography as nesting habitat (Benvenuti, 2016; Hartley and Weldon, 2020) has been proposed for increasing reproductive success of saltmarsh sparrows. The efficacy of this management technique is supported by anecdotal evidence of saltmarsh sparrows using naturally elevated areas (for example, natural sediment deposits and small berms) and is being evaluated through pilot testing (Hartley and Weldon, 2020). The lack of information to predict management benefits may have contributed to the exclusion of building elevated nesting habitat from optimal portfolios, suggesting that this and other methods to improve nest success might warrant further investigation. Future iterations of the decision model might consider additional actions targeting saltmarsh sparrows. For example, studies have suggested the acquisition of adjacent parcels for inland marsh-migration (Wiest and others, 2014) and manipulation of tidal hydrology (Hartley and Weldon, 2020) as actions that may support saltmarsh sparrow nesting success, but these mechanisms need further study. Ultimately, limiting declines of saltmarsh sparrow populations will likely depend on creating high-quality, high-elevation marsh habitat (Hartley and Weldon, 2020).

Third, the conversion of uplands to wetlands driven by sea-level rise may be the most important determinant of future marsh area. In the absence of anthropogenic barriers to marsh migration, land conversion is controlled by the slope and cover of coastal uplands; the stresses to upland vegetation caused by salinity and inundation; and synergistic disturbance events such as storms and insect outbreaks (Kirwan and Gedan, 2019). In this prototype, cutting and removing trees was identified as a possible management action to facilitate marsh migration in three marsh management units (table 3), but this action was never selected during optimization exercises. Deconstructing the objective of maintaining the extent of the marsh platform into subordinate objectives and performance metrics related to both horizontal and vertical gains and losses may help focus decision making on the various drivers of marsh area.

Fourth, although reducing the extent of Phragmites is a management concern in the Furbish marsh management unit, Phragmites control through use of herbicides was not selected for any optimal portfolio. The transparency of the structured decision-making framework reveals the tradeoffs associated with applying herbicide to reduce the spread of invasive plants. In this instance, controlling invasive plants was predicted to yield very slight increases in the percent cover of native vegetation and the density of nekton (table 3), and the change in management benefits associated with achieving these specific objectives was not detectable (table 4). However, spraying herbicide, which is a potential environmental contaminant, had direct negative consequences on the objective to minimize herbicide use and was predicted to decrease the total management benefit (table 4). Thus, the benefits associated with use of herbicide to reduce invasive plants may not offset the negative value of applying environmental contaminants. These results emphasize the importance that refuge managers have placed on controlling spread of invasive plants through various methods, including tidal restoration and hand pulling (FWS, 2007). This prototype could be adapted to allow managers to evaluate the relative expected benefits and detriments of chemical and other control methods.

Finally, the constrained optimizations analyzed in this report were based on underestimated approximations of management costs, as they did not include expenditures that may be necessary in advance to mobilize equipment. A detailed list of actual expenses is being compiled as salt marsh management is undertaken around the region, including staff time for project planning as well as materials, equipment, contracts, and staff time for site preparation and implementation. This will allow future iterations of the decision model to include more accurate cost estimates.

The prototype model for the Rachel Carson National Wildlife Refuge provides a useful tool for decision making that can be updated in the future with new data and information. Updates might include changes to the overall objectives structure as well as improvements to elements of the decision model. For example, the spatial and temporal variability inherent in parameter estimates were not quantified during rapid prototyping. Previously, preliminary sensitivity analysis revealed little effect of incorporating ecological variation in abundance of marsh-obligate breeding birds on the optimal solutions for Prime Hook National Wildlife Refuge 
(Neckles and others, 2015). This lends confidence to use of this framework for decision making; however, including probability distributions for each performance metric in the decision model could be a high priority for future prototypes. Importantly, baseline data were unavailable for some metrics included in this decision model (abundance of American black ducks, density of spiders, and change in marsh surface elevation relative to sea-level rise). In particular, although spider communities have been proposed as sensitive ecological indicators (Wheater and others, 2000) and spider abundance was found to increase in a New Jersey salt marsh following restoration of smooth cordgrass (Gratton and Denno, 2005), there remains a paucity of data on salt marsh spiders overall. Spider densities in this prototype were estimated based on a single study (Döbel and others, 1990). The effectiveness of spiders as an indicator of trophic health would depend on improved understanding of how different spider taxa respond to salt marsh management actions. Future monitoring of salt marsh integrity performance metrics will be useful to refine baseline parameter estimates and to determine the background rate of change in the absence of management actions; feedback from measured responses to management actions around the region will help reduce uncertainties surrounding management predictions.

The structured decision-making framework applied here to selected marsh management units in the Rachel Carson National Wildlife Refuge is based on a hierarchy of regional objectives and regional value functions relating performance metrics to perceived management benefits. It will be important to ensure that subsequent iterations reflect evolving management objectives and desired outcomes at regional and refuge scales. Elements of the decision model could be further adapted, for example through differential weighting of objectives or altered value functions, to reflect specific, local management goals and mandates. Future optimization analyses that use this framework could also incorporate additional constraints on action selection, such as ensuring that particular actions within individual marsh management units are included in optimal management portfolios, to further tailor the model to refuge-specific needs.

\section{References Cited}

Adamowicz, S.C., Wilson, G., Burdick, D.M., Ferguson, W., and Topping, R., 2020, Farmers in the marsh-Lessons from history and case studies for the future: Wetland Science and Practice, v. 37, no. 3, p. 183-195. [Also available at https://issuu.com/societyofwetlandscientists/docs/ july_2020_wsp/59.]

Benvenuti, B., 2016, Nesting adaptations and conservation of a threatened tidal marsh-nesting bird the salt marsh sparrow: Durham, University of New Hampshire, Master's thesis, 96 p. [Also available at https://scholars.unh.edu/thesis/1093/.]
Blomquist, S.M., Johnson, T.D., Smith, D.R., Call, G.P., Miller, B.N., Thurman, W.M., McFadden, J.E., Parkin, M.J., and Boomer, G.S., 2010, Structured decision-making and rapid prototyping to plan a management response to an invasive species: Journal of Fish and Wildlife Management, v. 1, no. 1, p. 19-32. [Also available at https://doi.org/ 10.3996/JFWM-025.]

Conroy, M.J., and Peterson, J.T., 2013, Decision making in natural resource management-A structured, adaptive approach: Chichester, United Kingdom, John Wiley and Sons, Ltd., 456 p. [Also available at https://doi.org/10.1002/ 9781118506196.]

Cowardin, L.M., Carter, V., Golet, F.C., and LaRoe, E.T., 1979, Classification of wetlands and deepwater habits of the United States: U.S. Fish and Wildlife Service FWS/ OBS-79/31, 131 p., accessed November 12, 2018, at https://www.fws.gov/wetlands/Documents/Classification-ofWetlands-and-Deepwater-Habitats-of-the-United-States.pdf.

Döbel, H.G., Denno, R.F., and Coddington, J.A., 1990, Spider (Araneae) community structure in an intertidal salt marsh - Effects of vegetation structure and tidal flooding: Environmental Entomology, v. 19, no. 5, p. 1356-1370. [Also available at https://doi.org/10.1093/ee/19.5.1356.]

Elphick, C.E., Meiman, S., and Rubega, M.A., 2015, Tidalflow restoration provides little nesting habitat for a globally vulnerable saltmarsh bird: Restoration Ecology, v. 23, no. 4, p. 439-446. [Also available at https://doi.org/10.1111/ rec.12194.]

Garrard, G.E., Rumpff, L., Runge, M.C., and Converse, S.J., 2017, Rapid prototyping for decision structuringAn efficient approach to conservation decision analysis, in Bunnefeld, N., Nicholson, E., and Milner-Gulland, E.J., eds., Decision-making in conservation and natural resource management: Cambridge, United Kingdom, Cambridge University Press, p. 46-64. [Also available at https://doi.org/10.1017/9781316135938.003.]

Gedan, K.B., Altieri, A.H., and Bertness, M.D., 2011, Uncertain future of New England salt marshes: Marine Ecology Progress Series, v. 434, p. 229-237. [Also available at https://doi.org/10.3354/meps09084.]

Gedan, K.B., Silliman, B.R., and Bertness, M.D., 2009, Centuries of human-driven change in salt marsh ecosystems: Annual Review of Marine Science, v. 1, no. 1, p. 117-141. [Also available at https://doi.org/10.1146/ annurev.marine.010908.163930.]

Gratton, C., and Denno, R.F., 2005, Restoration of arthropod assemblages in a Spartina salt marsh following removal of the invasive plant Phragmites australis: Restoration Ecology, v. 13, no. 2, p. 358-372. [Also available at https://doi.org/10.1111/j.1526-100X.2005.00045.x.] 
Gregory, R., Failing, L., Harstone, M., Long, G., McDaniels, T., and Ohlson, D., 2012, Structured decision making-A practical guide to environmental management choices: Chichester, United Kingdom, John Wiley and Sons, Ltd., 299 p. [Also available at https://doi.org/10.1002/ 9781444398557.]

Gregory, R.S., and Keeney, R.L., 2002, Making smarter environmental management decisions: Journal of the American Water Resources Association, v. 38, no. 6, p. 1601-1612. [Also available at https://doi.org/10.1111/ j.1752-1688.2002.tb04367.x.]

Hammond, J.S., Keeney, R.L., and Raiffa, H., 1999, Smart choices-A practical guide to making better life decisions: Boston, Harvard Business School Press, 242 p.

Hartley, M.J., and Weldon, A.J., eds., 2020, Saltmarsh sparrow conservation plan-Partners working to conserve salt marshes and the birds that depend on them: Atlantic Coast Joint Venture, 122 p., accessed March 11, 2021, at https://acjv.org/saltmarsh-sparrow-plan/.

Keeney, R.L., and Raiffa, H., 1993, Decisions with multiple objectives-Preferences and value tradeoffs: Cambridge, United Kingdom, Cambridge University Press, 569 p. [Also available at https://doi.org/10.1017/CBO9781139174084.]

Kirkwood, C.W., 1997, Strategic decision makingMultiobjective decision analysis with spreadsheets: Belmont, Calif., Duxbury Press, 345 p.

Kirwan, M.L., and Gedan, K.B., 2019, Sea-level driven land conversion and the formation of ghost forests: Nature Climate Change, v. 9, no. 6, p. 450-457. [Also available at https://doi.org/10.1038/s41558-019-0488-7.]

Kirwan, M.L., and Megonigal, J.P., 2013, Tidal wetland stability in the face of human impacts and sea-level rise: Nature, v. 504, no. 7478, p. 53-60. [Also available at https://doi.org/ 10.1038/nature12856.]

Konisky, R.A., Burdick, D.M., Dionne, M., and Neckles, H.A., 2006, A regional assessment of salt marsh restoration and monitoring in the Gulf of Maine: Restoration Ecology, v. 14 , no. 4, p. 516-525. [Also available at https://doi.org/ 10.1111/j.1526-100X.2006.00163.x.]

Lynch, J.C., Hensel, P., and Cahoon, D.R., 2015, The surface elevation table and marker horizon technique-A protocol for monitoring wetland elevation dynamics: National Park Service Natural Resource Report NPS/NCBN/NRR 2015/1078, [variously paged], accessed August 24, 2018, at https://irma.nps.gov/DataStore/DownloadFile/531681.

Multi-Resolution Land Characteristics Consortium, 2020, NLCD 2011 land cover (CONUS): Multi-Resolution Land Characteristics Consortium database, accessed March 17, 2021, at https://www.mrlc.gov/data.
National Audubon Society, [undated], Important bird areasWells - Rachel Carson/Webhannet/Wells bay saltmarshes: National Audubon Society web page, accessed January 21, 2021, at https://www.audubon.org/important-bird-areas/ wells-rachel-carsonwebhannetwells-bay-saltmarshes.

Neckles, H.A., Guntenspergen, G.R., Shriver, W.G., Danz, N.P., Wiest, W.A., Nagel, J.L., and Olker, J.H., 2013, Identification of metrics to monitor salt marsh integrity on national wildlife refuges in relation to conservation and management objectives: U.S. Fish and Wildlife Service, prepared by U.S. Geological Survey, 226 p., accessed May 1, 2018, at https://ecos.fws.gov/ServCat/Reference/ Profile/37795.

Neckles, H.A., Lyons, J.E., Guntenspergen, G.R., Shriver, W.G., and Adamowicz, S.C., 2015, Use of structured decision making to identify monitoring variables and management priorities for salt marsh ecosystems: Estuaries and Coasts, v. 38, no. 4, p. 1215-1232. [Also available at https://doi.org/10.1007/s12237-014-9822-5.]

Pennings, S.C., and Bertness, M.D., 2001, Salt marsh communities, in Bertness, M.D., Gaines, S.D., and Hay, M.E., eds., Marine community ecology: Sunderland, Mass., Sinauer Associates, p. 289-316.

Roman, C.T., 2017, Salt marsh sustainability - Challenges during an uncertain future: Estuaries and Coasts, v. 40, no. 3, p. 711-716. [Also available at https://doi.org/10.1007/ s12237-016-0149-2.]

Roman, C.T., and Burdick, D.M., eds., 2012, Tidal marsh restoration-A synthesis of science and management: Washington, D.C., Island Press, 406 p. [Also available at https://link.springer.com/content/pdf/10.5822\%2F978-161091-229-7.pdf.]

Steinkamp, M., 2008, New England/mid-Atlantic coast bird conservation (BCR 30) implementation plan: Atlantic Coast Joint Venture, 251 p., accessed August 15, 2018, at https://www.acjv.org/BCR_30/BCR30_June_23_2008_ final.pdf.

U.S. Fish and Wildlife Service [FWS], 2007, Rachel Carson National Wildlife Refuge-Comprehensive conservation plan and environmental assessment: U.S. Fish and Wildlife Service, [variously paged], accessed January 30, 2021, at https://www.fws.gov/refuge/rachel_carson/what_we_do/ finalccp.html.

U.S. Fish and Wildlife Service [FWS], 2016, Salt marsh integrity and Hurricane Sandy vegetation, bird and nekton data: U.S. Fish and Wildlife Service database, accessed March 16, 2021, at https://ecos.fws.gov/ServCat/Reference/ Profile/121918. 
U.S. North American Bird Conservation Initiative, 2020, Bird conservation regions: U.S. North American Bird Conservation Initiative web page, accessed July 6, 2020, at https://nabci-us.org/resources/bird-conservation-regions/.

Wheater, C.P., Cullen, W.R., and Bell, J.R., 2000, Spider communities as tools in monitoring reclaimed limestone quarry landforms: Landscape Ecology, v. 15, no. 5, p. 401-406. [Also available at https://doi.org/10.1023/ A:1008171023039.]

Wiest, W.A., Shriver, W.G., and Messer, K.D., 2014, Incorporating climate change with conservation planning-A case study for tidal marsh bird conservation in Delaware, USA: Journal of Conservation Planning, v. 10, p. 25-42. [Also available at https://udspace.udel.edu/handle/ 19716/17120.]

Wigand, C., Ardito, T., Chaffee, C., Ferguson, W., Paton, S., Raposa, K., Vandemoer, C., and Watson, E., 2017, A climate change adaptation strategy for management of coastal marsh systems: Estuaries and Coasts, v. 40, no. 3, p. 682-693. [Also available at https://doi.org/10.1007/s12237015-0003-y.] 


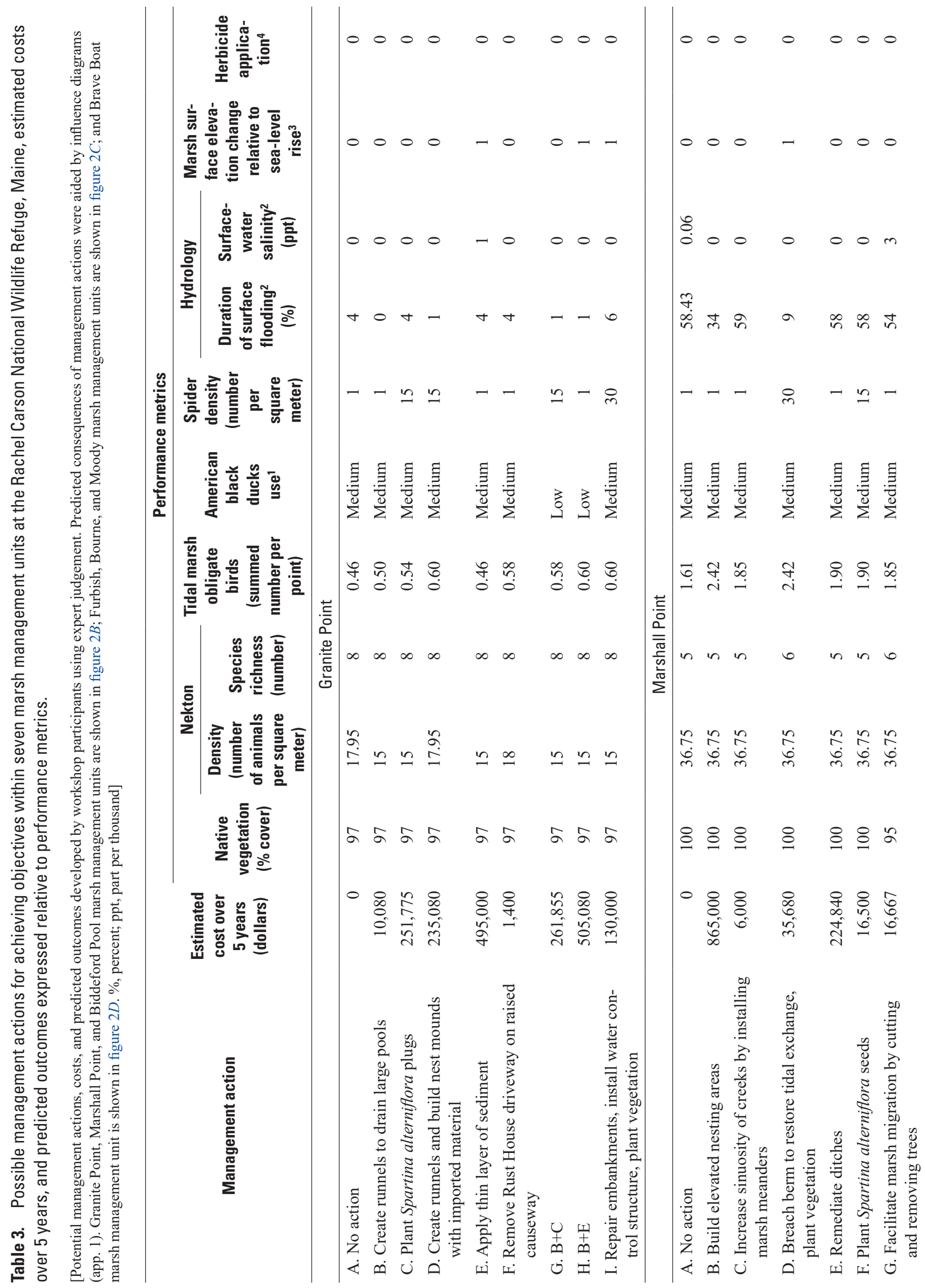


Table 3
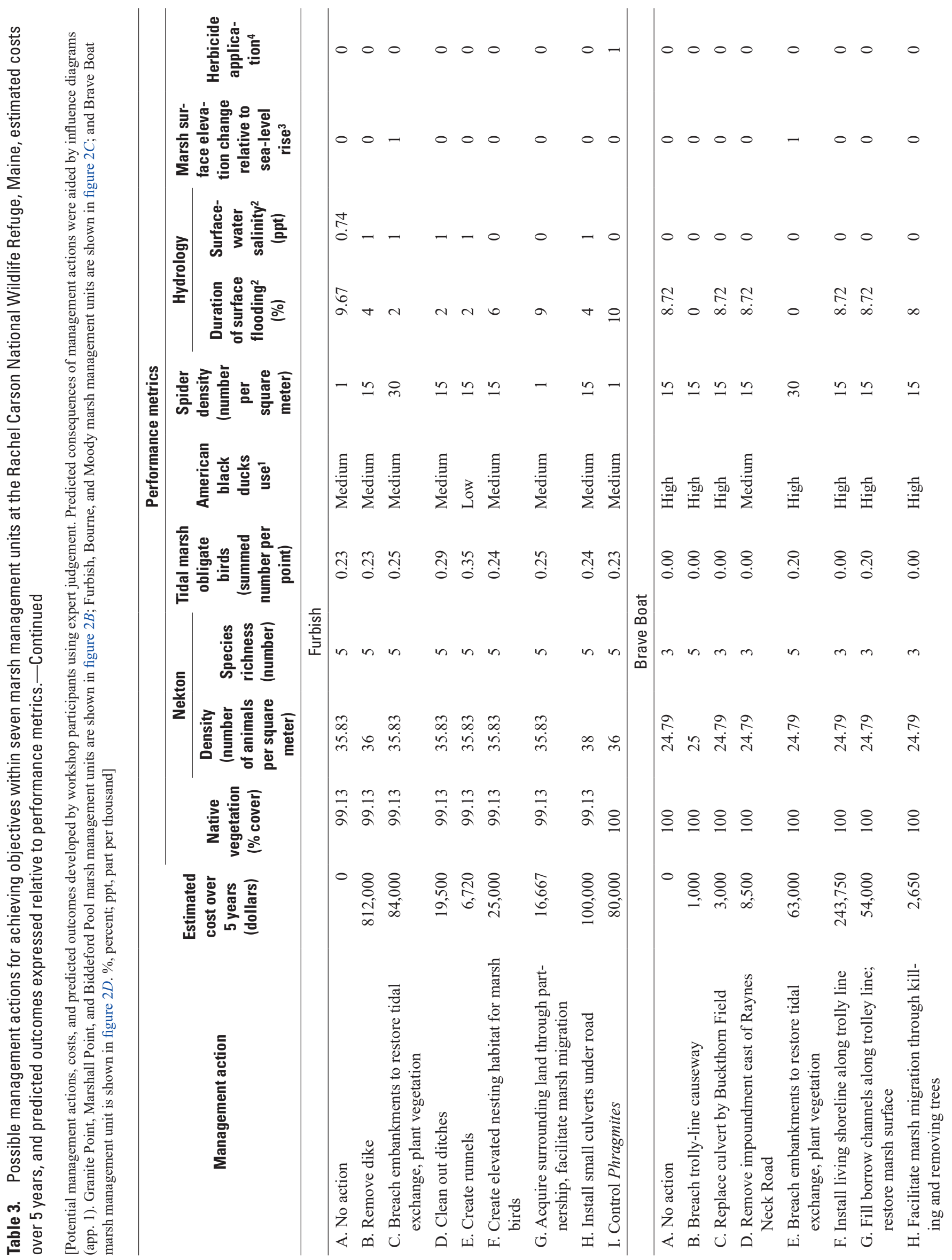


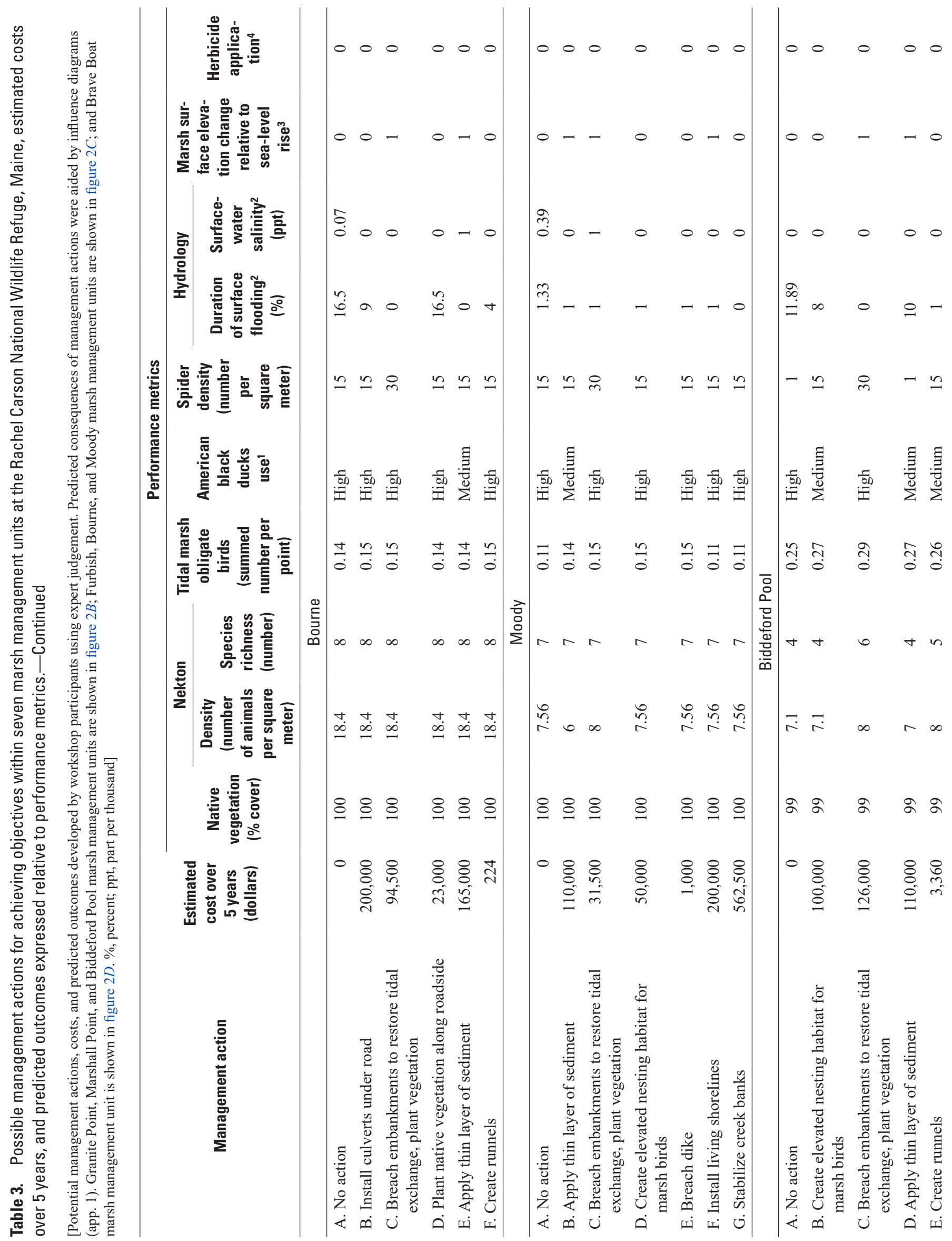




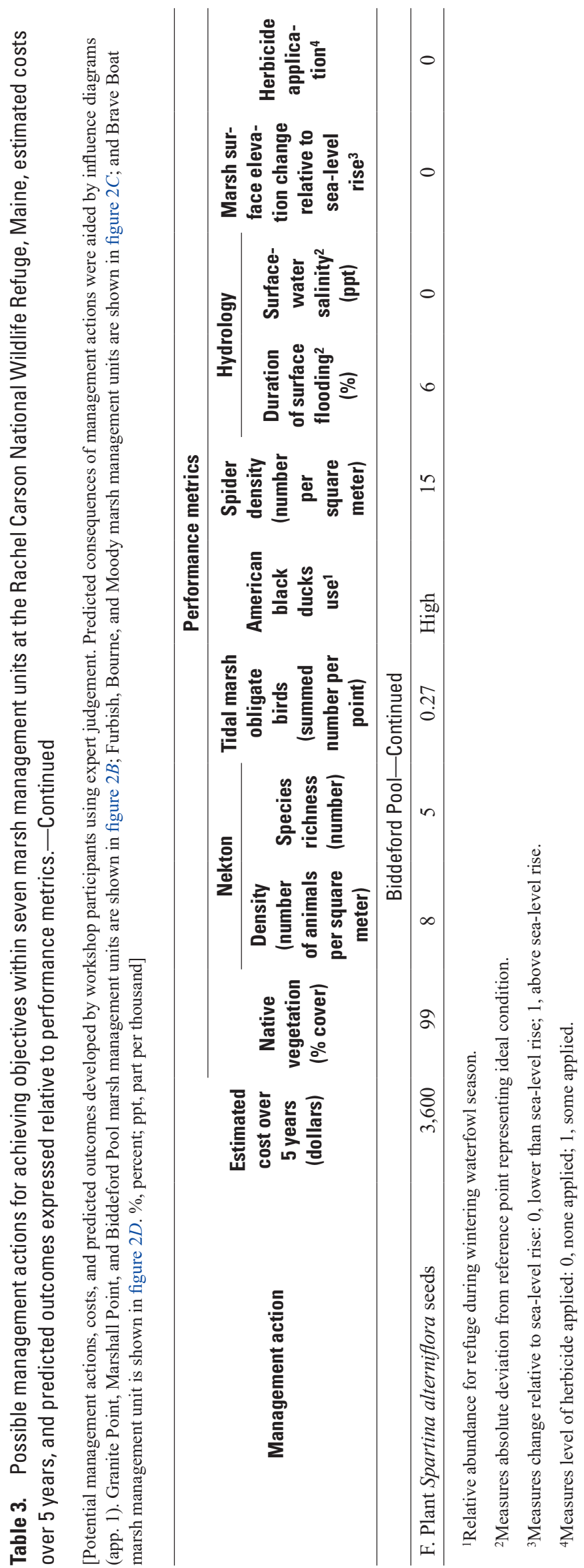




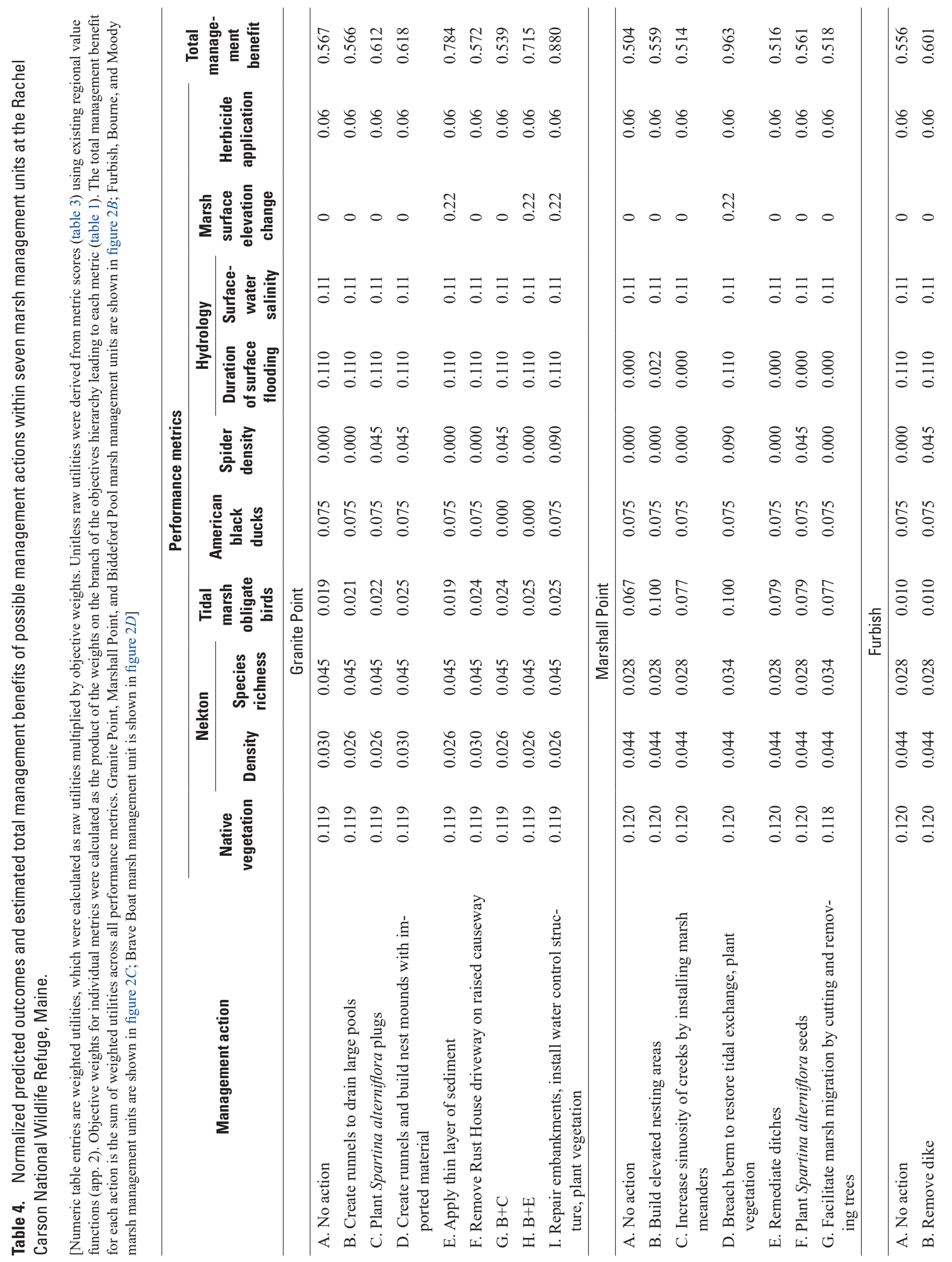


莺

.흥

品

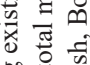

量产

元

ब류

象.

远

苞焉

g

实. 总

卷

긍

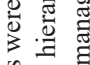

品

寻

3

党焉

5 .

해요

ปี

$\sum$ ก

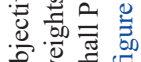

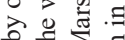

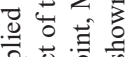

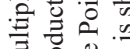

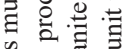

일

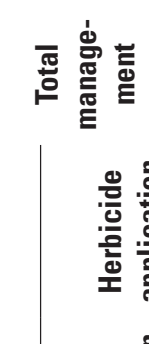

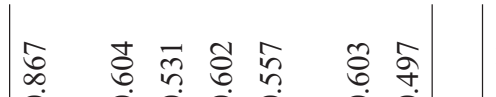

i

రิธి

:

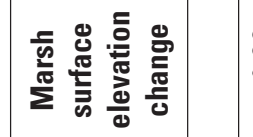

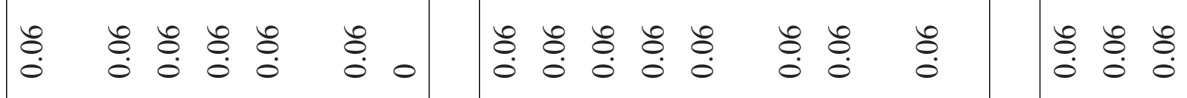

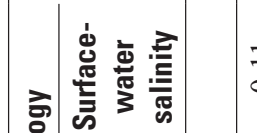

$\begin{array}{lllllll}\text { กิ } & 0 & 0 & 0 & 0 & 0 & 0\end{array}\left|\begin{array}{llllllll}0 & 0 & 0 & 0 & 0 & 0 & 0 & 0\end{array}\right| \begin{array}{llll}1 & 0 & 0\end{array}$

을

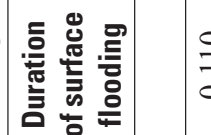

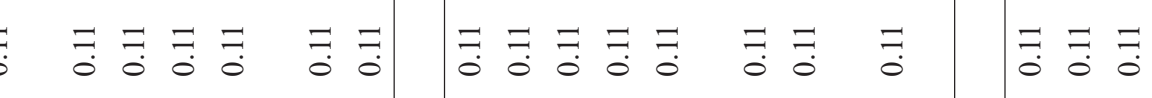

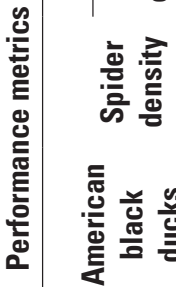

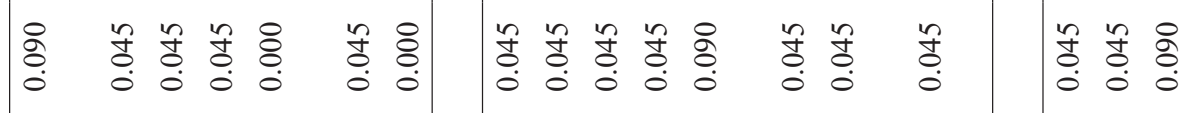

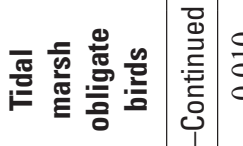

$\begin{array}{lllllll}n & n & 8 & n & n & n & n \\ 0 & 0 & 0 & 0 & 0 & 0 & 0 \\ 0 & 0 & 0 & 0 & 0 & 0 & 0\end{array}$

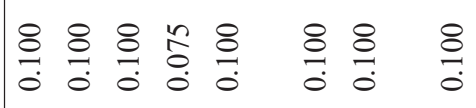

$\circ 8$

三 :

完

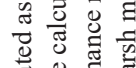

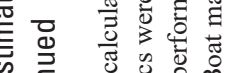

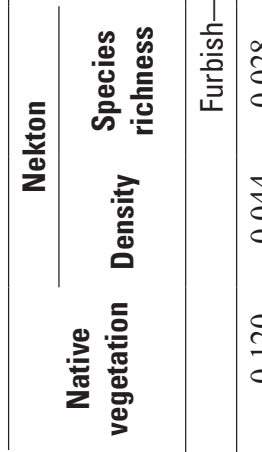

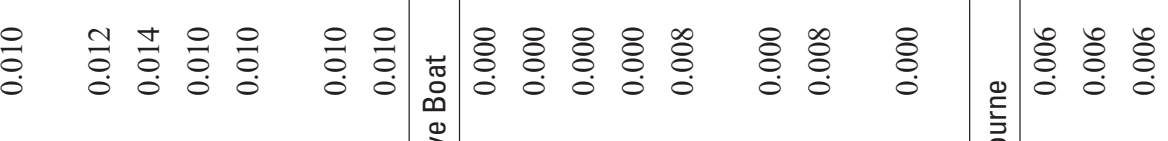
(1)

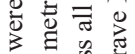

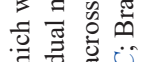

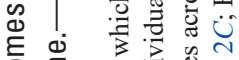

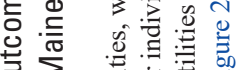

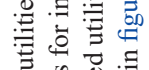

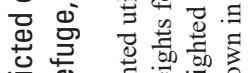

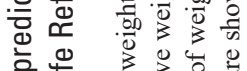

立幽

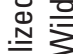

ช.

产完. 号

要

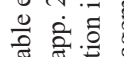

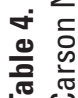

:

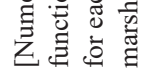

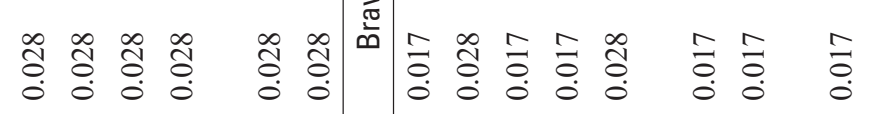

$\begin{array}{lll}n & n & n \\ 0 & f & f \\ 0 & 0 & 0 \\ 0 & 0 & 0\end{array}$

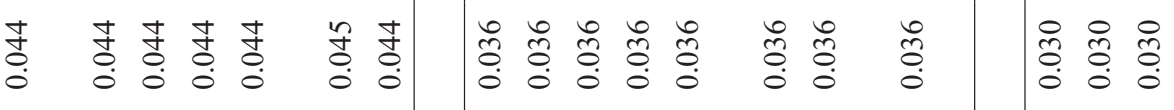

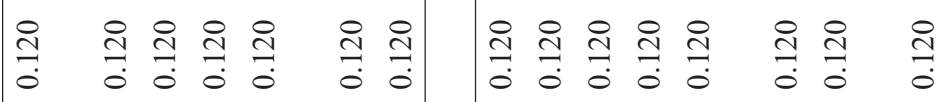

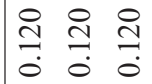

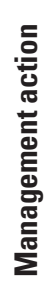

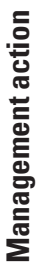
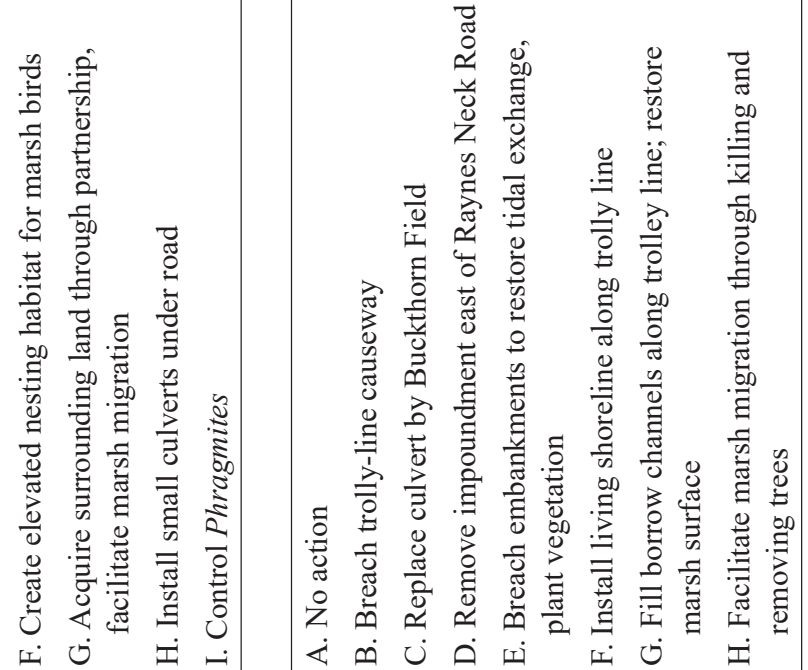

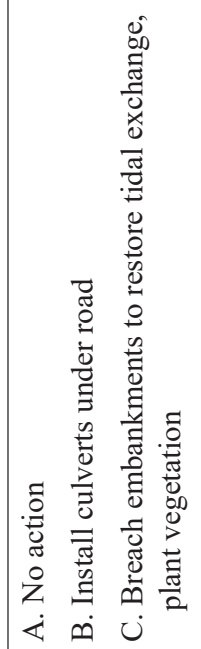




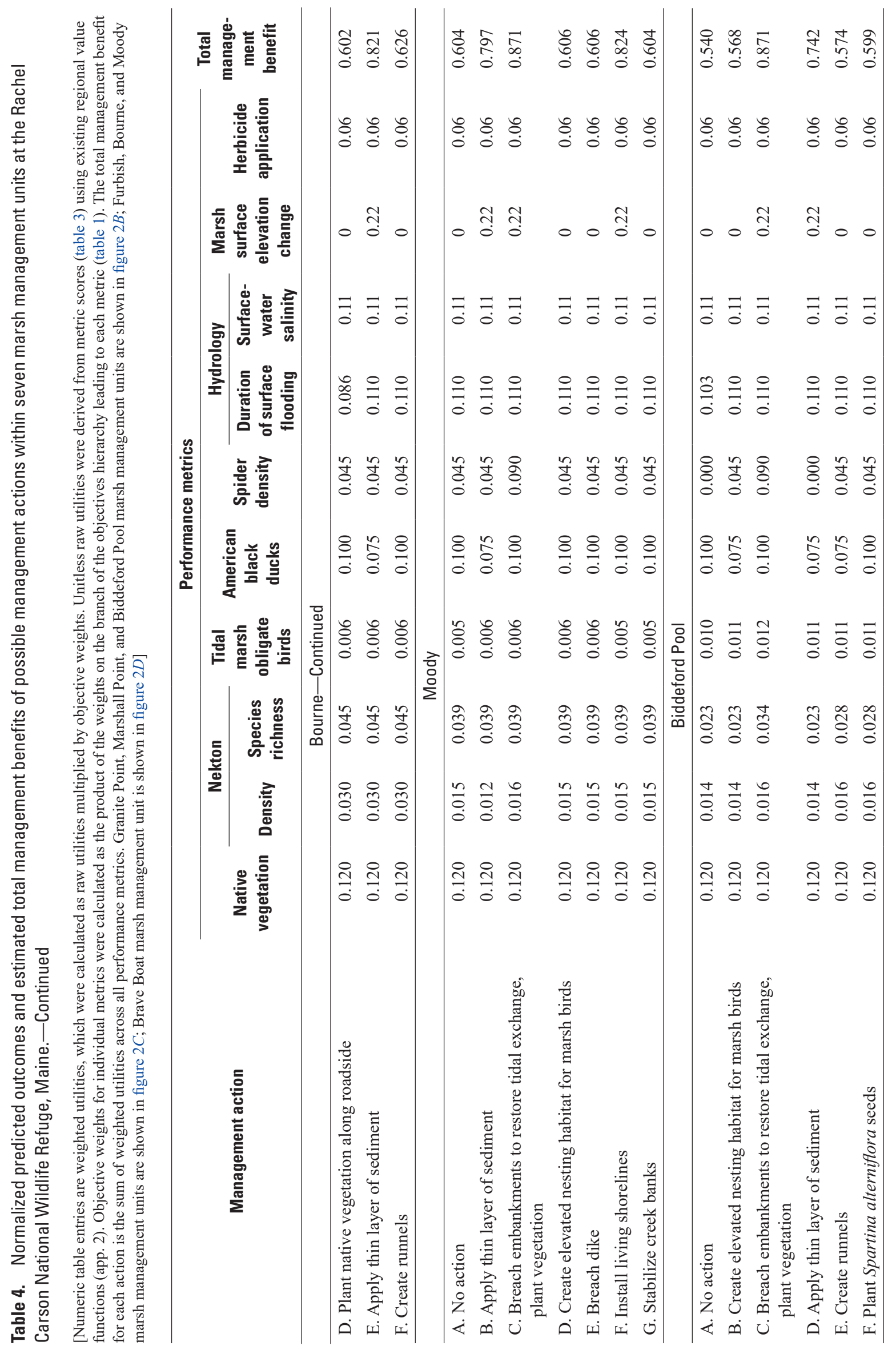




\section{Appendix 1. Regional Influence Diagrams}

The influence diagrams (following the style of prototype diagrams in Neckles and others, 2015) in this appendix (figs. 1.1-1.8) relate possible management strategies to performance metrics. Shapes represent elements of decisions, as follows: rectangles for actions, rectangles with rounded corners for deterministic factors, ovals for stochastic events, and hexagons for consequences expressed as a performance metric.

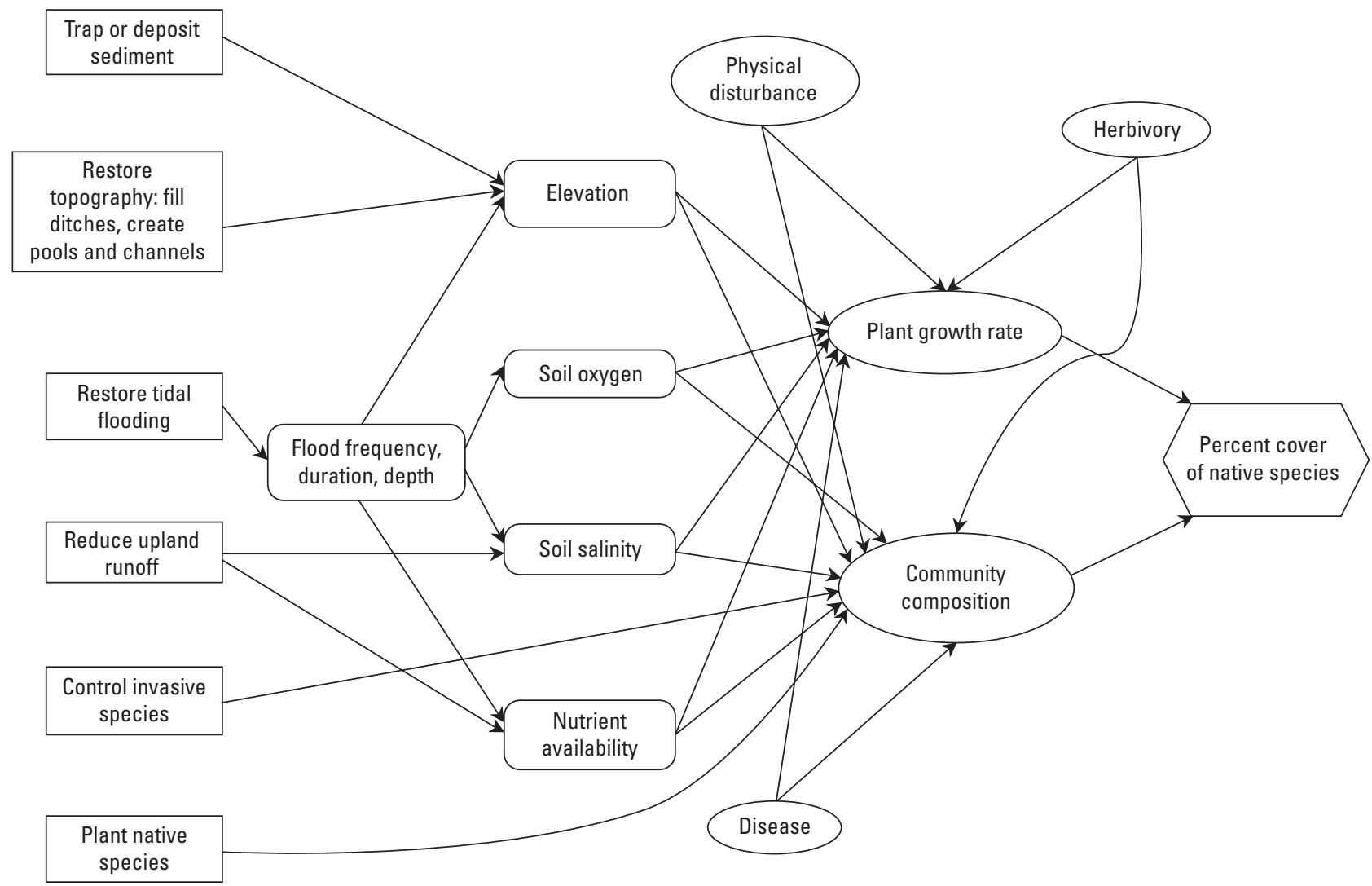

Figure 1.1. Influence diagram used to estimate percent cover of native vegetation in response to implementing certain management actions. 


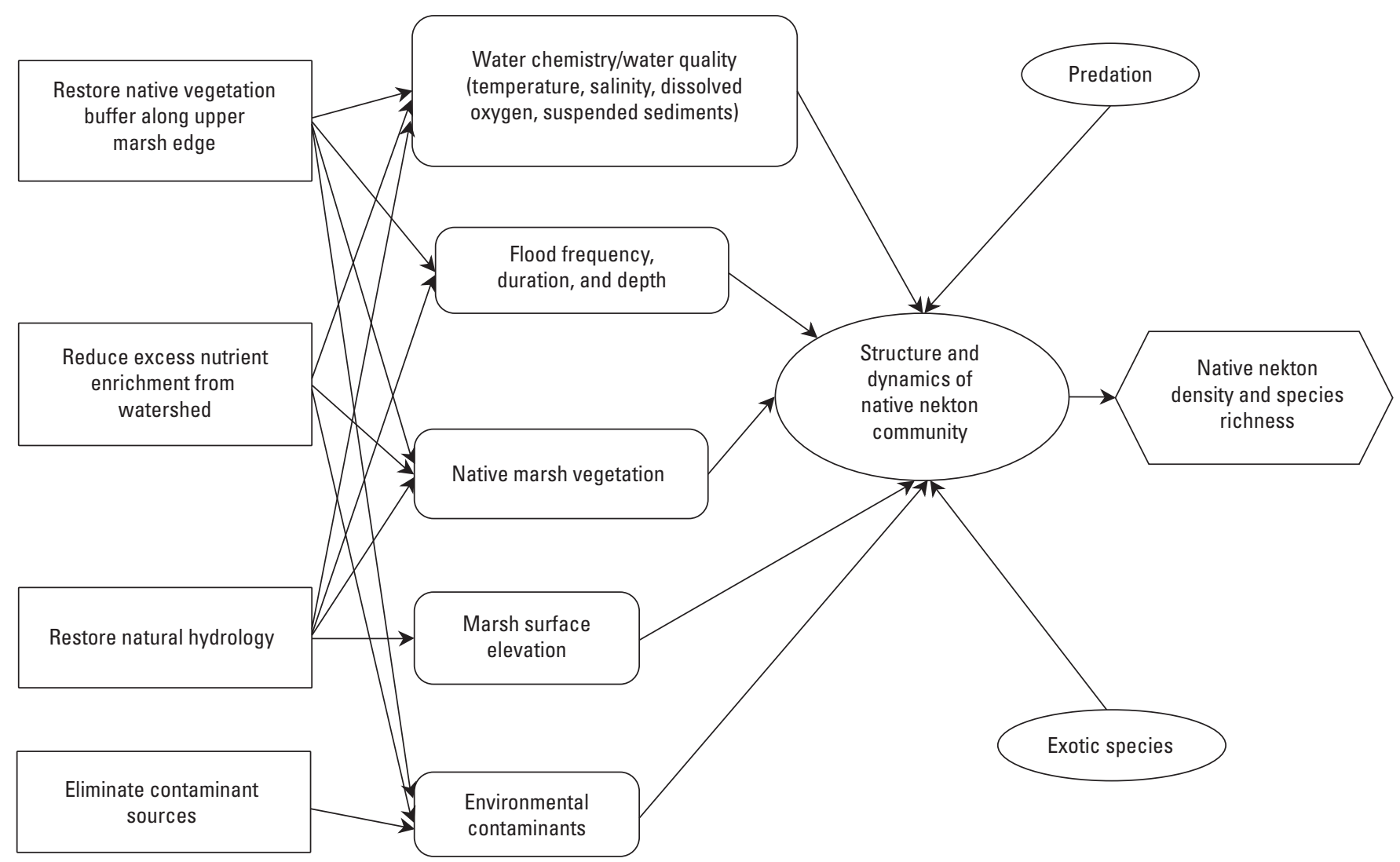

Figure 1.2. Influence diagram used to estimate nekton density and species richness in response to implementing certain management actions. 


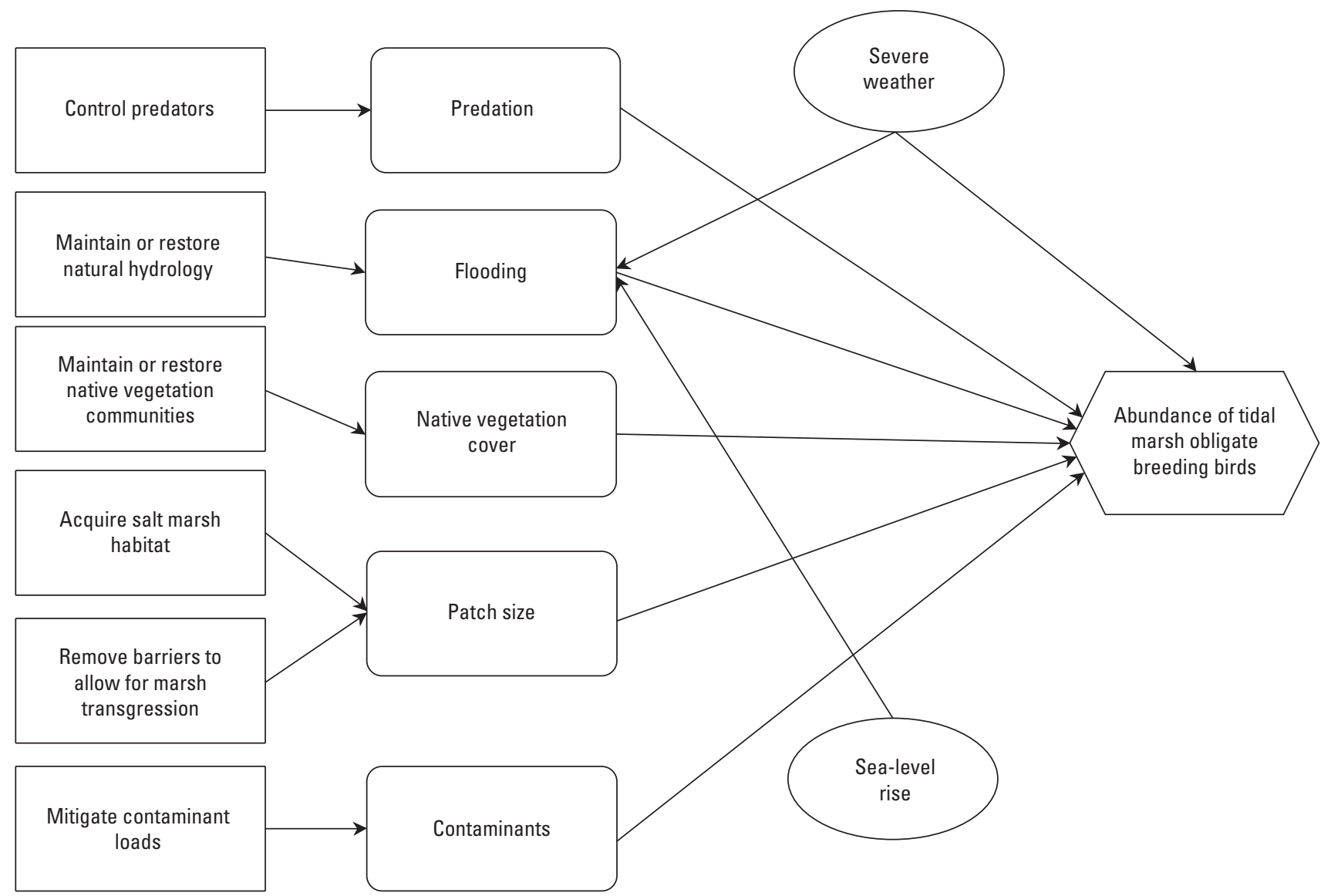

Figure 1.3. Influence diagram used to estimate abundance of tidal marsh obligate breeding birds in response to implementing certain management actions. 


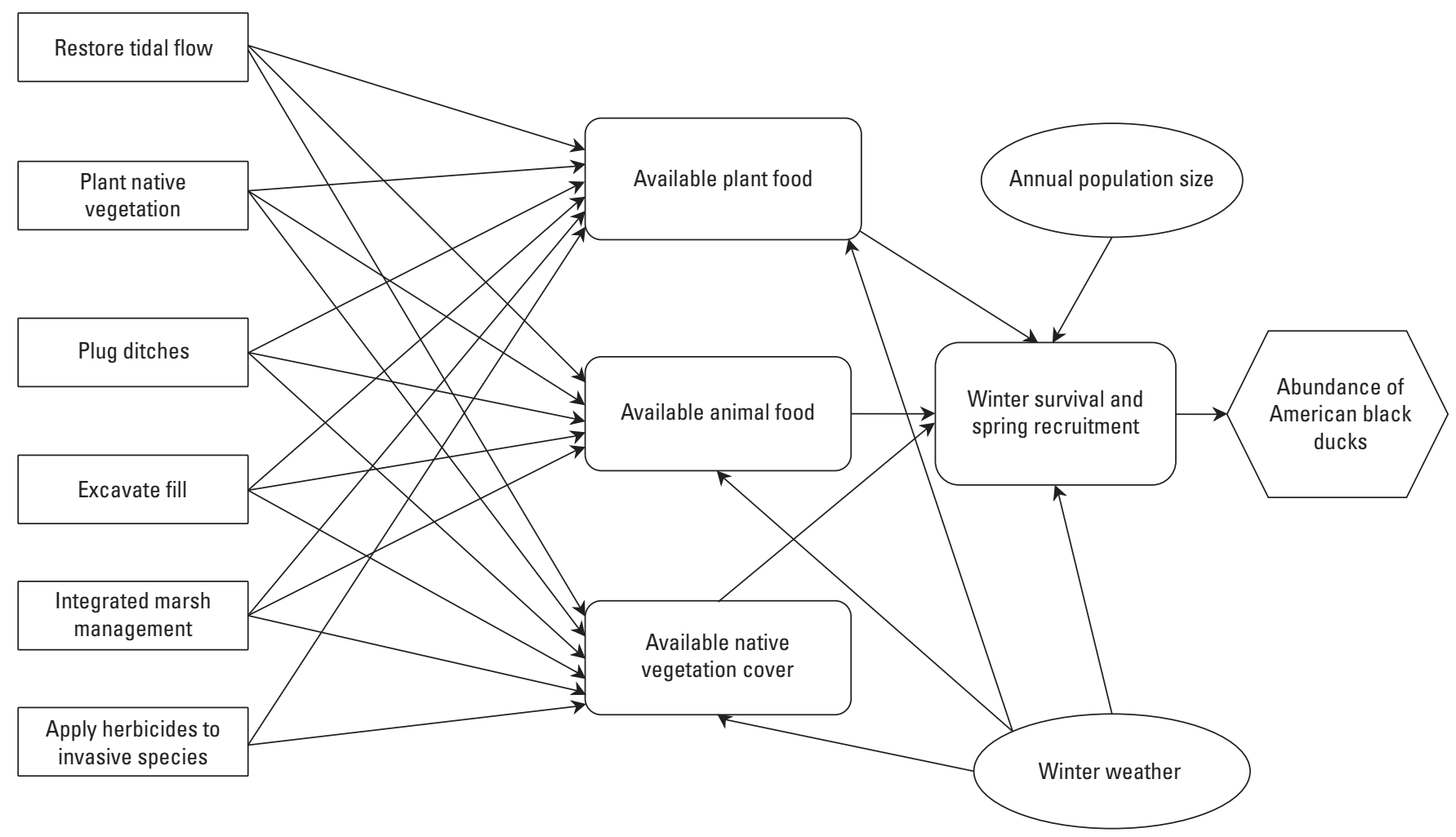

Figure 1.4. Influence diagram used to estimate abundance of American black ducks in winter, as indicator species for nonbreeding wetland birds, in response to implementing certain management actions. 


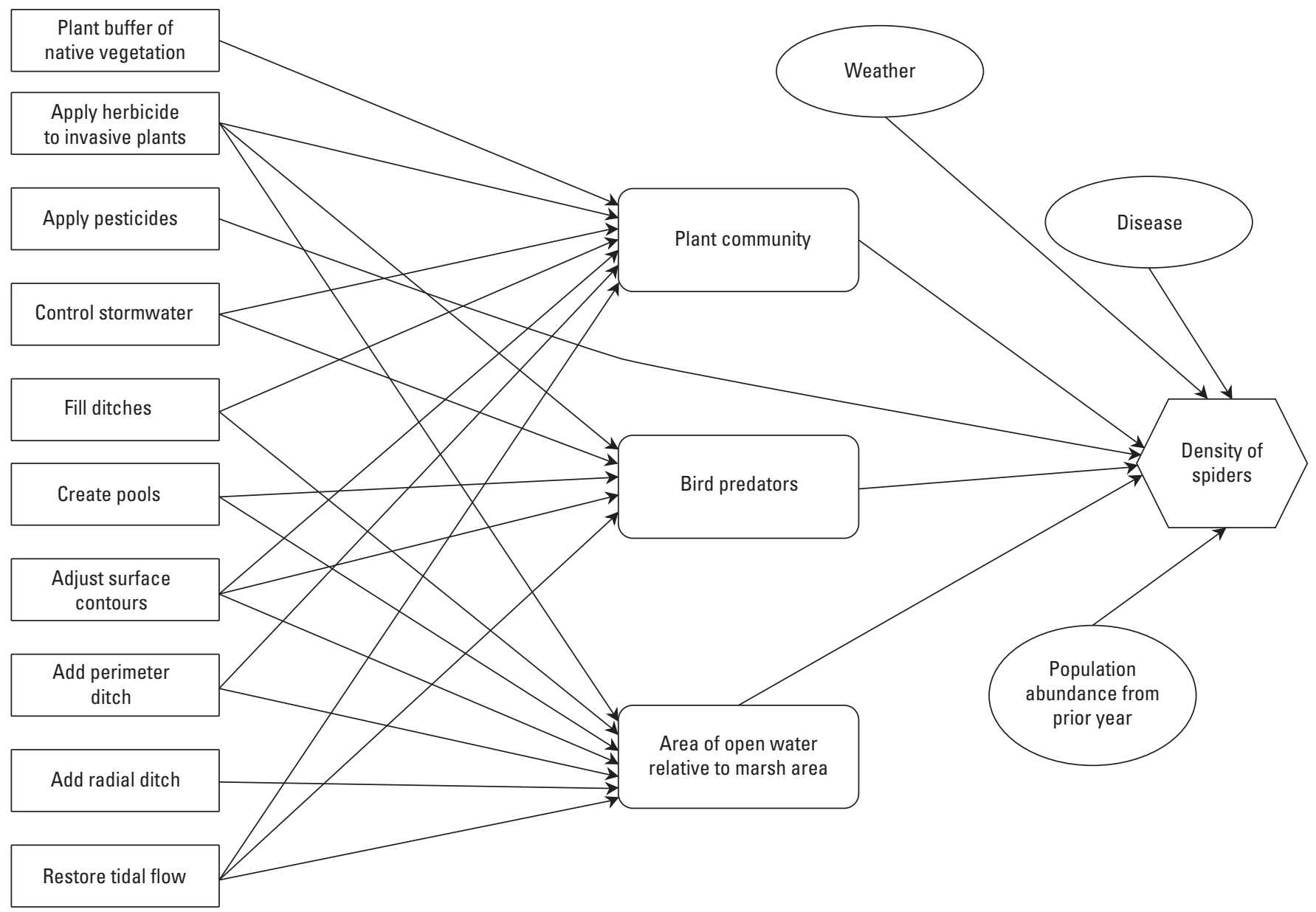

Figure 1.5. Influence diagram used to estimate density of spiders, as indicator of trophic health, in response to implementing certain management actions. 


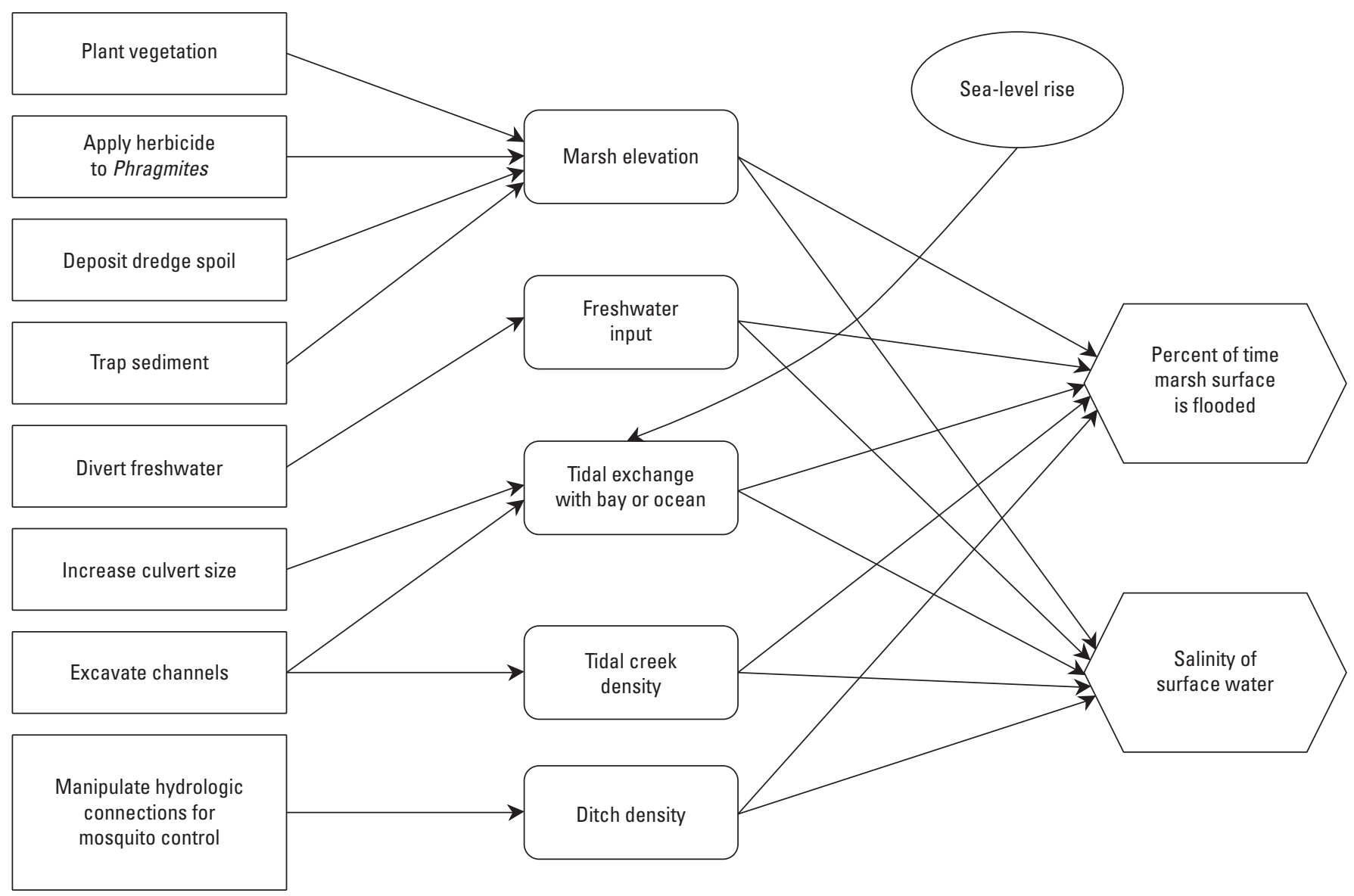

Figure 1.6. Influence diagram used to estimate percent of time marsh surface is flooded and salinity of marsh surface water in response to implementing certain management actions. 


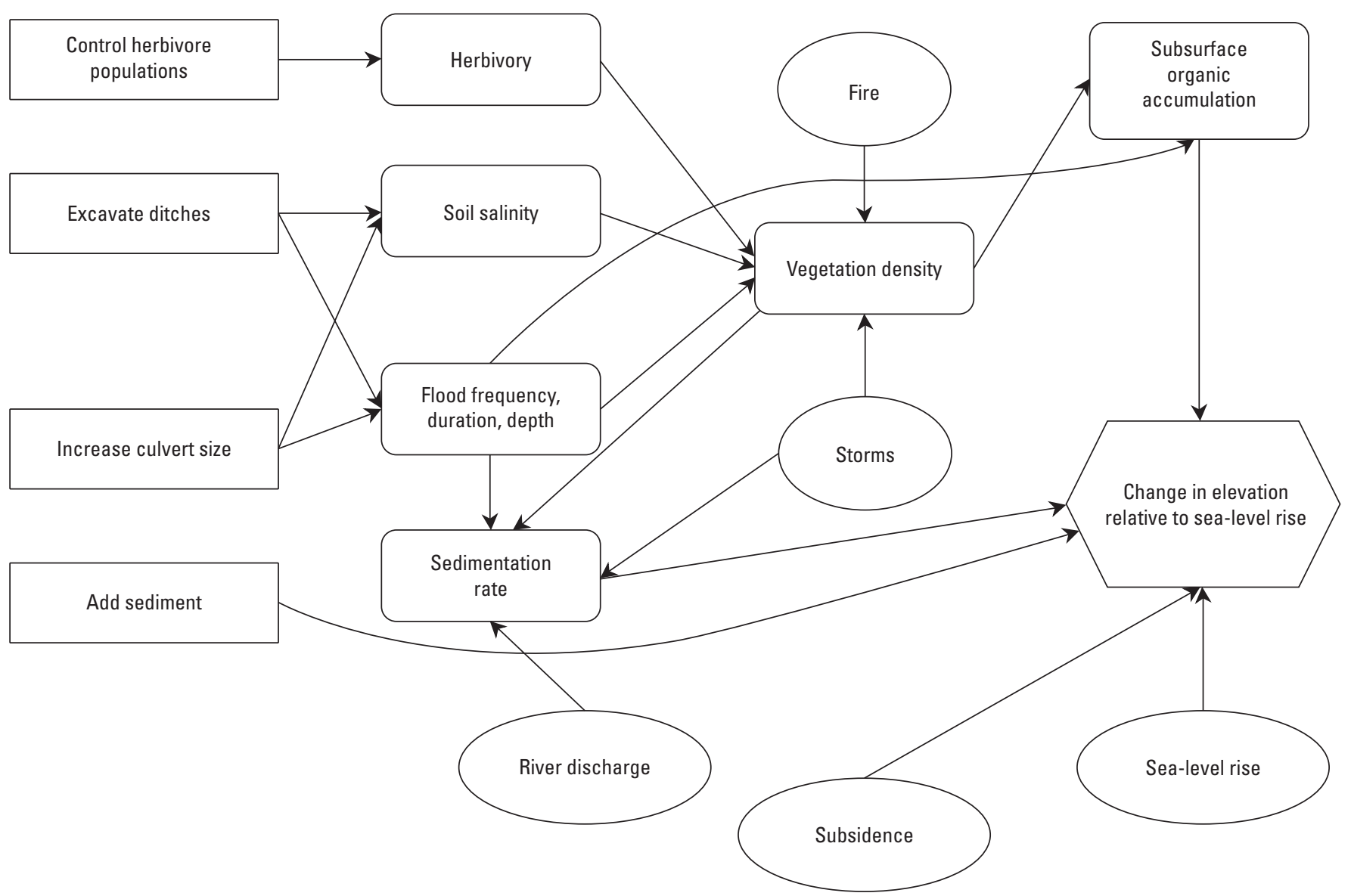

Figure 1.7. Influence diagram used to estimate change in elevation of the marsh surface relative to sea-level rise in response to implementing certain management actions.

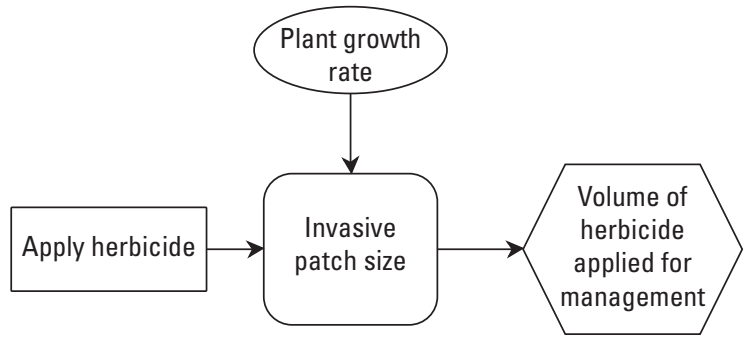

Figure 1.8. Influence diagram used to estimate volume of herbicide that could be applied if a decision was made to use chemical control for removing unwanted vegetation.

\section{Reference Cited}

Neckles, H.A., Lyons, J.E., Guntenspergen, G.R., Shriver, W.G., and Adamowicz, S.C., 2015, Use of structured decision making to identify monitoring variables and management priorities for salt marsh ecosystems: Estuaries and Coasts, v. 38, no. 4, p. 1215-1232. [Also available at https://doi.org/10.1007/s12237-014-9822-5.] 


\section{Appendix 2. Utility Functions for the Rachel Carson National Wildlife Refuge}

Utilities $[u(x)]$ are derived as monotonically increasing, monotonically decreasing, or step functions over the range of performance metric $x$. In the functions in figures 2.1-2.10, $x$, Low, High, and $\rho$ are expressed in performance metric units; Low and High represent the endpoints of the given metric range for the Rachel Carson National Wildlife Refuge; and $\rho$ represents a shape parameter derived by stakeholder elicitation (Neckles and others, 2015). Break points in step functions were also derived by stakeholder elicitation.

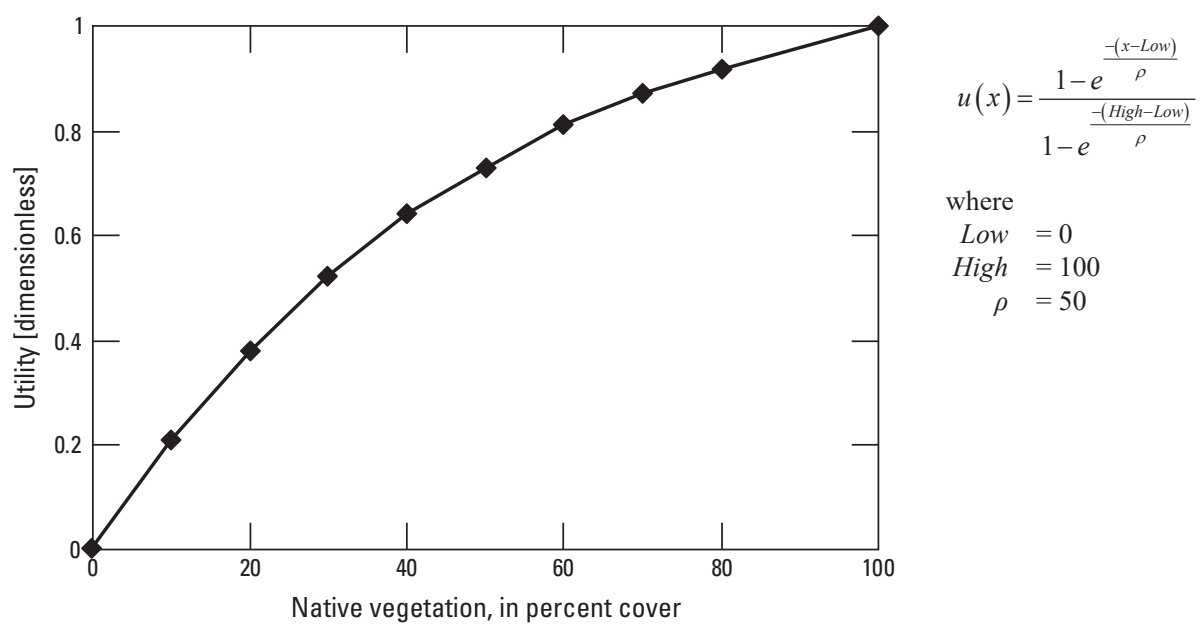

Figure 2.1. Native vegetation at the Rachel Carson National Wildlife Refuge, Maine.

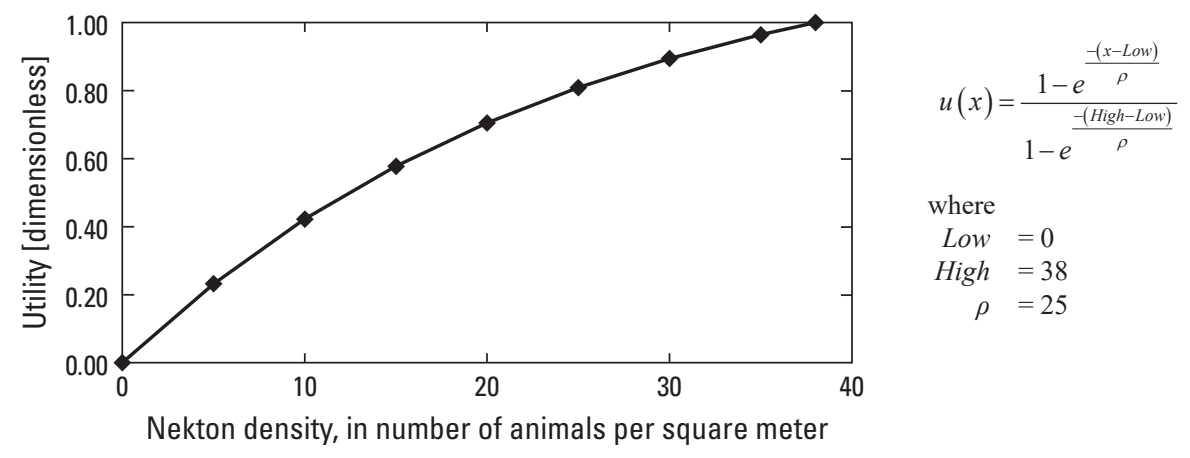

Figure 2.2. Native nekton density at the Rachel Carson National Wildlife Refuge, Maine. 


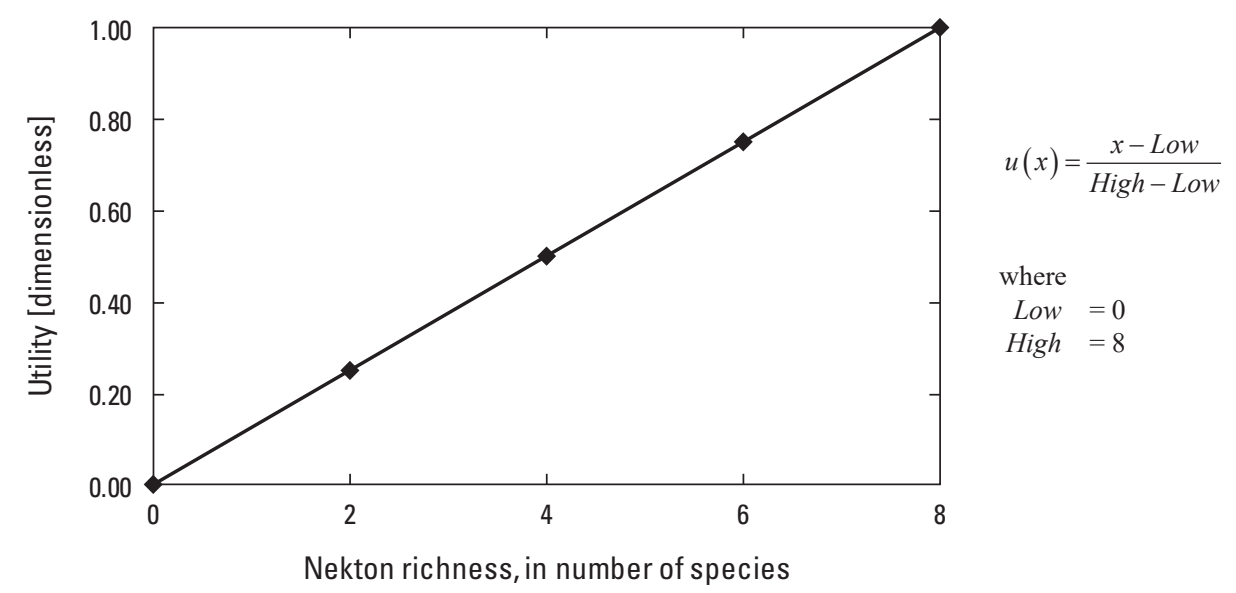

Figure 2.3. Native nekton species richness at the Rachel Carson National Wildlife Refuge, Maine.

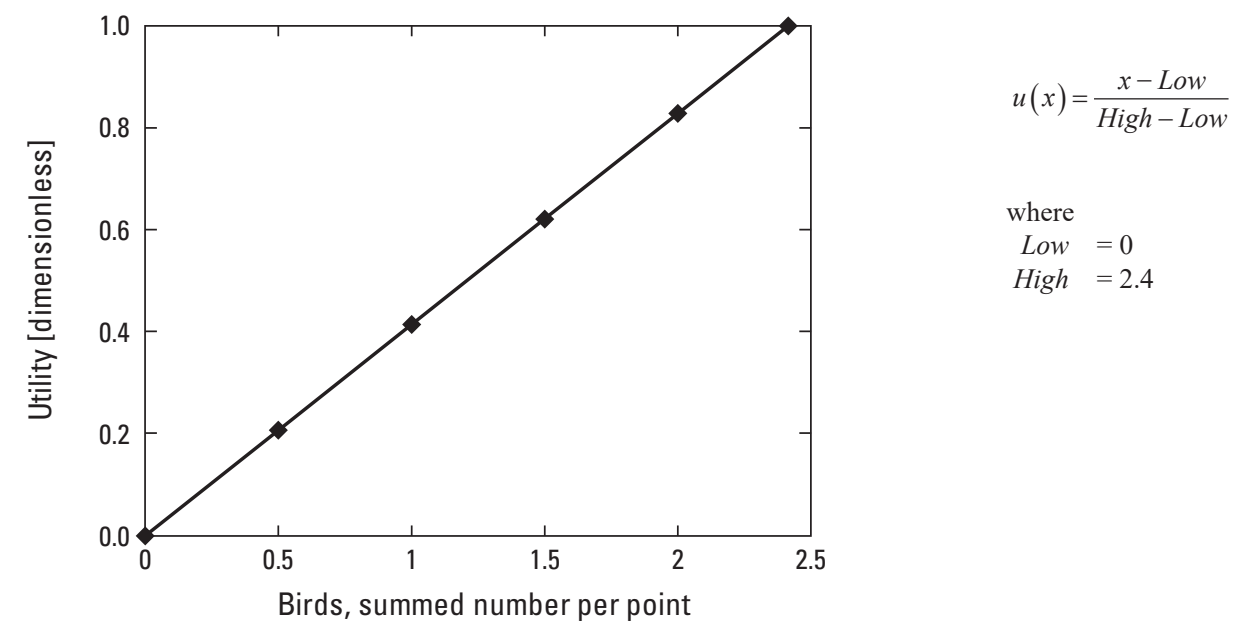

Figure 2.4. Tidal marsh obligate birds at the Rachel Carson National Wildlife Refuge, Maine.

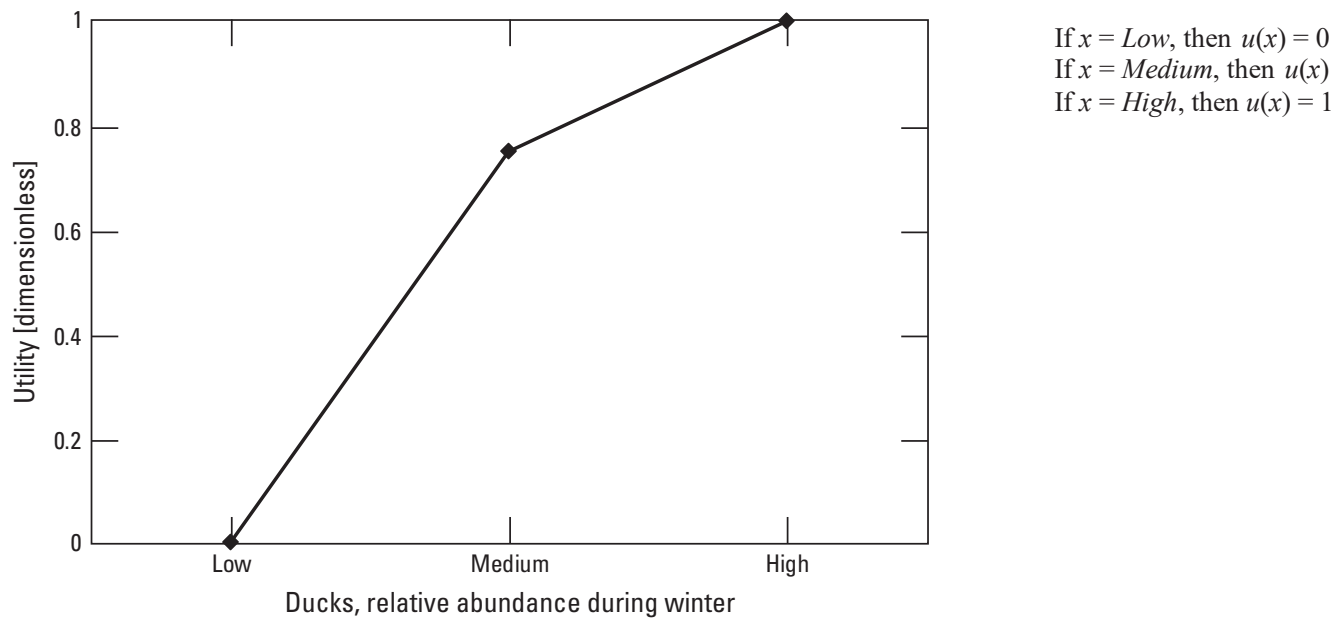

Figure 2.5. American black ducks at the Rachel Carson National Wildlife Refuge, Maine. 


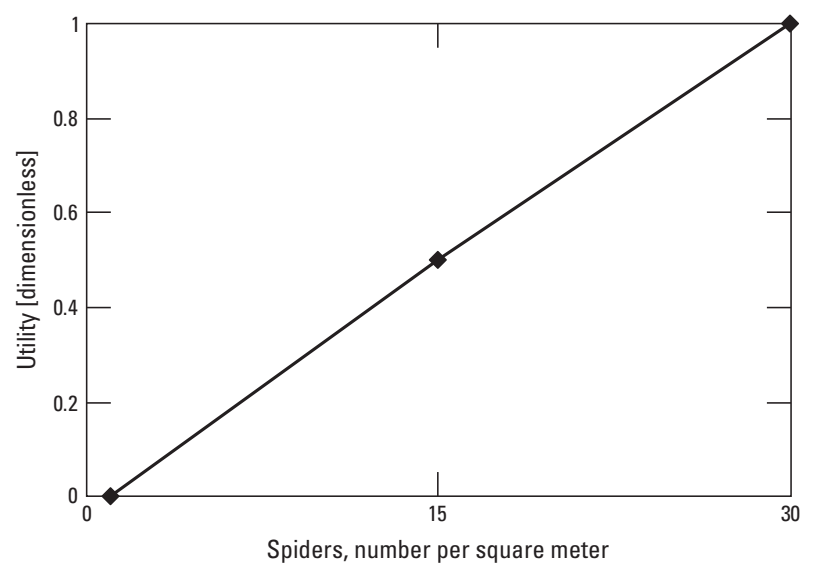

$$
\begin{aligned}
& \text { If } x \leq 15 \text {, then } u(x)=0.5 \times \frac{x-1}{14} \\
& \text { If } x>15 \text {, then } u(x)=0.5+\left(0.5 \times \frac{x-15}{15}\right)
\end{aligned}
$$

Figure 2.6. Marsh spiders at the Rachel Carson National Wildlife Refuge, Maine.

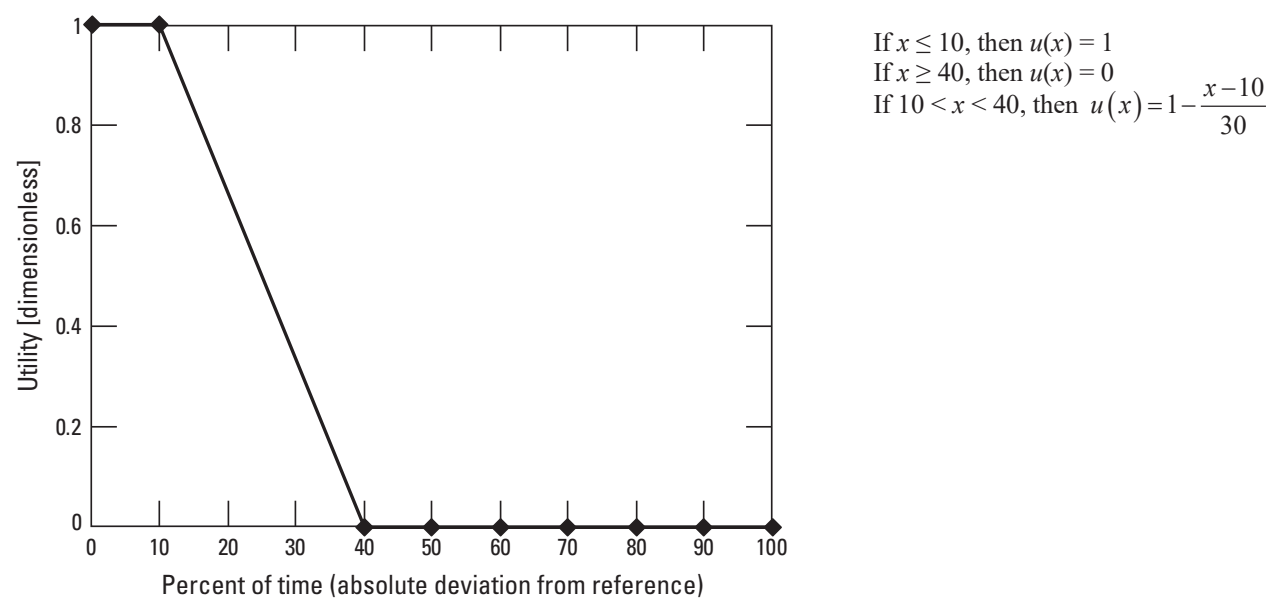

Figure 2.7. Duration of surface flooding at the Rachel Carson National Wildlife Refuge, Maine.

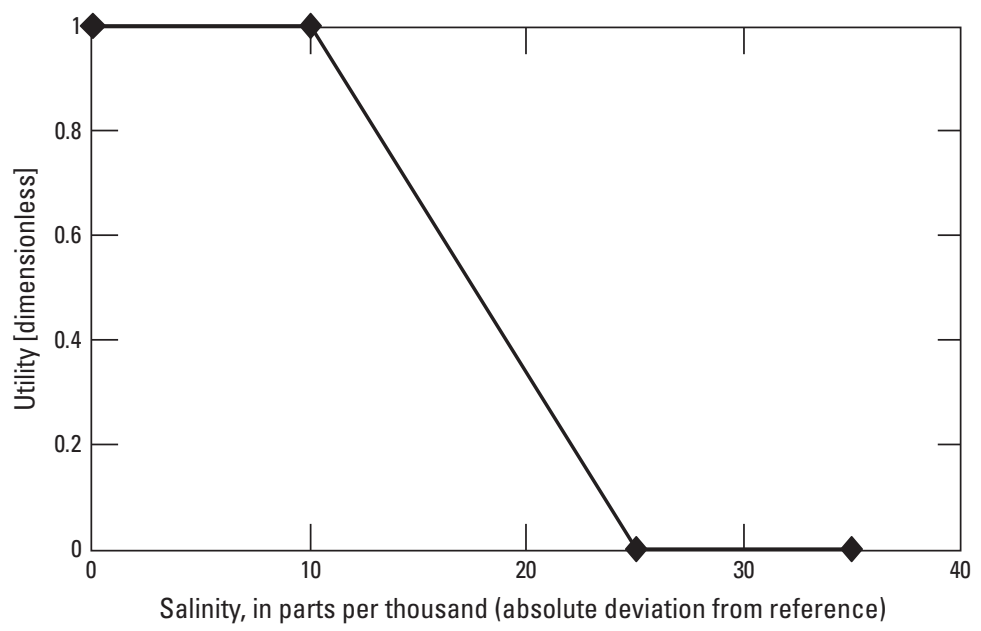

If $x \leq 10$, then $u(x)=1$

If $x \geq 25$, then $u(x)=0$

If $10<x<25$, then $u($

Figure 2.8. Salinity of surface water at the Rachel Carson National Wildlife Refuge, Maine. 


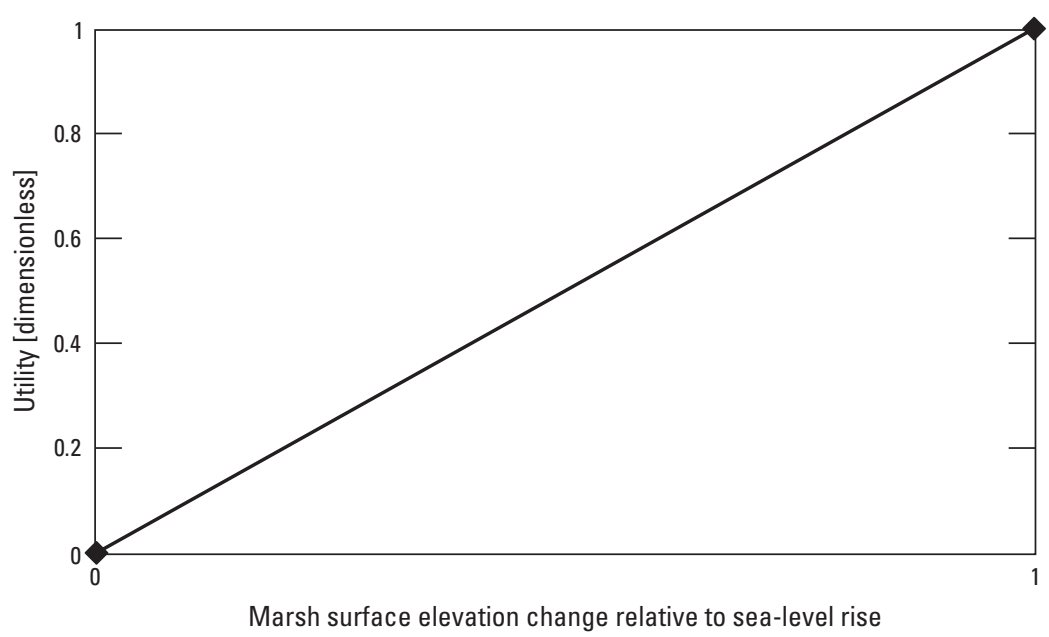

$$
\begin{aligned}
& u(x)=\frac{x-\text { Low }}{\text { High }- \text { Low }} \\
& \text { where } \quad=0 \text {, lower than sea-level rise } \\
& \qquad \begin{aligned}
\text { How } \quad=1, \text { above sea-level rise }
\end{aligned}
\end{aligned}
$$

Figure 2.9. Change in marsh surface elevation relative to sea-level rise at the Rachel Carson National Wildlife Refuge, Maine.

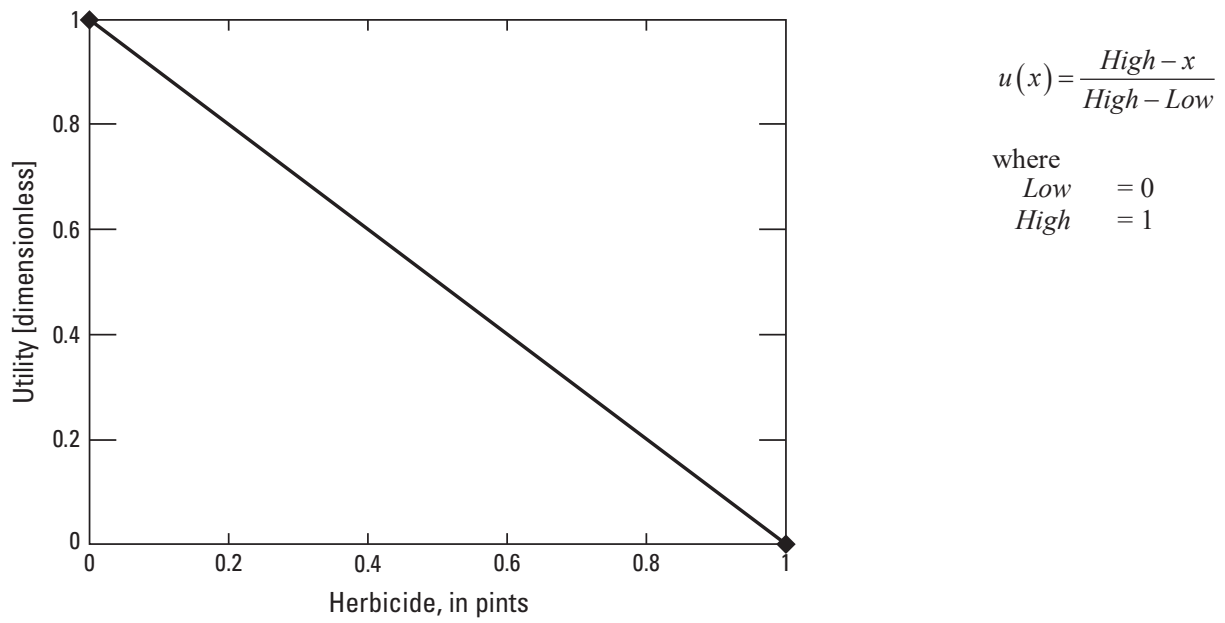

Figure 2.10. Application of herbicides at the Rachel Carson National Wildlife Refuge, Maine.

\section{Reference Cited}

Neckles, H.A., Lyons, J.E., Guntenspergen, G.R., Shriver, W.G., and Adamowicz, S.C., 2015, Use of structured decision making to identify monitoring variables and management priorities for salt marsh ecosystems: Estuaries and Coasts, v. 38, no. 4, p. 1215-1232. [Also available at https://doi.org/10.1007/s12237-014-9822-5.] 

For more information, contact:

Director, Eastern Ecological Science Center

U.S. Geological Survey

11649 Leetown Road

Kearneysville, WV 25430

or visit our website at

https://www.usgs.gov/centers/eesc

Publishing support provided by the

Pembroke Publishing Service Center 
